ARTICLE

\title{
From a Financial to an Entity Model of ESG
}

\author{
Iain MacNeil ${ }^{1}$ Irene-marié Esser ${ }^{2,3}$
}

Accepted: 13 December 2021 / Published online: 10 January 2022

(c) The Author(s) 2022

\begin{abstract}
ESG investing evolved over time from the earlier concept of CSR. The process of evolution moved the focus from the external impact of corporate activities to the risk and return implications for financial investors of failing to address ESG issues in their portfolio selection and corporate engagement. The bridge between the two approaches was the framing of sustainability in the early part of the millennium as an overarching concept that could be mapped onto the supply of capital and the techniques employed by institutional investors. The financial model of ESG investing is now the standard approach around the world and is reflected in ESG ratings, codes, guidance and regulatory rules. It focuses on the role of capital and investors in driving change in sustainability practices and pays much less attention to the role of board decision-making and directors' fiduciary duties. In this research, we trace the origins and trajectory of this change in emphasis from CSR to ESG and attempt to explain why it occurred. We identify shortcomings in the financial model of ESG investing and propose an alternative 'entity' model, which we argue would more effectively promote sustainability in the corporate sector around the world.
\end{abstract}

Keywords ESG $\cdot$ CSR $\cdot$ Sustainability $\cdot$ Fiduciary duty $\cdot$ Stakeholders $\cdot$ Due diligence

Iain MacNeil

Iain.Macneil@glasgow.ac.uk

$\bowtie$ Irene-marié Esser

Irene-marie.Esser@glasgow.ac.uk

1 Alexander Stone Chair of Commercial Law, University of Glasgow, Glasgow, UK

2 Professor of Corporate Law and Governance, University of Glasgow, Glasgow, UK

3 Extraordinary Professor, Stellenbosch University, Stellenbosch, South Africa 


\section{Introduction}

Sustainability is now a key theme in corporate and financial law. It has many strands but one of the key overarching themes is a focus on how corporate governance and financial regulation might contribute to resolving or mitigating externalities. That debate is nested within the broader question of whether corporate governance and financial regulation are the most appropriate techniques for addressing these issues. It is often argued that (Pigouvian) taxes or further regulation would be better solutions in the sense that they would address (at least some) externalities more directly and consistently. ${ }^{1}$ While we see a role for both taxes and further regulation, we start from the viewpoint that corporate governance and financial regulation have a role to play in the transition to a sustainable economic model, especially in a global context in which political agreement on taxes and further regulation seems unlikely. Moreover, since the institutional frameworks surrounding corporate governance and financial regulation have already demonstrated some capability to mobilise voluntary action in connection with sustainability, ${ }^{2}$ we believe that further movement in that direction is possible.

While corporate social responsibility (CSR) had been the dominant paradigm through which the social responsibility of business was framed for much of the latter part of the twentieth century, the pattern changed with the approach of the millennium. Sustainability emerged as a key concern and with it the proposition that investors should incorporate ESG factors into portfolio construction so as to mitigate environmental (especially climate change), social (especially human rights) and governance risks that would potentially harm investment performance over the long term. The financial model of ESG investing is now the standard approach around the world and is reflected in ESG metrics, ratings, guidance and regulatory rules. It focuses on the role of capital and investors in driving change in sustainability practices and pays less attention to the role of board decision-making and directors' fiduciary duties. In recent years, sustainability, CSR and ESG have co-existed and have often been treated as equivalents by practitioners, standard setters and academics alike. In our view, however, the apparent similarities conceal some fundamental differences.

Viewed in terms of their fundamentals, the three approaches are quite different. In line with other commentators, ${ }^{3}$ we see sustainability as the overarching concept, with CSR and ESG as sub-sets that operate within the corporate and financial domains respectively. Sustainability is focused most explicitly on externalities and, from a corporate governance perspective, on how the de facto norm of shareholder primacy has limited the internalisation of externalities through a focus on

\footnotetext{
1 See generally Leicester (2013). For an overview of carbon taxes see https://www.unpri.org/priblogs/costing-jobs-or-cutting-emissions-what-is-the-real-impact-of-europes-carbon-taxes/6712.article (accessed 15 May 2021).

2 See further Sect. 2.1 below.

3 See, for example, https://www.measurabl.com/esg-vs-sustainability-whats-the-difference/ (accessed 15 May 2021).
} 
shareholder interests. ${ }^{4}$ The ethical foundation of CSR means in principle that the focus is on doing the right thing in the context of the operational setting of the business. In that sense the ethical choice is not framed as an instrument for improving financial performance, albeit that the expectation might be that observance of ethical standards would, in the long term, have that effect. ESG is focused on financial risk and return and therefore integration of ESG factors into the investment process has the primary purpose of improving returns over the long term by mitigating the risks associated with those ESG factors.

There is undoubtedly overlap between the different approaches, especially at the level of implementation, where techniques such as metrics or key performance indicators (KPIs) may address concerns that are common across all three approaches. Nevertheless, we believe that the fundamental difference in the objectives of each approach means that they cannot be fully reconciled. Their co-existence must therefore inevitably lead to tensions that cannot be resolved. Those tensions may lie below the surface when one approach dominates the others-and that is how we perceive the current situation, with ESG as the dominant paradigm (see Fig. 1). ${ }^{5}$

Put another way, it could be said that the three approaches represent a trilemma, in the sense that there could not be simultaneously a full implementation of all three. Sustainability, as the overarching concept, could be effectively combined with either CSR or ESG but not simultaneously with both. We aim to demonstrate this in three stages. In Sect. 2 we outline the evolution of ESG and key attributes of CSR and ESG respectively so as to differentiate them. In Sect. 3 we explain, by reference to fiduciary duty, why the financialised model of ESG superseded CSR as the

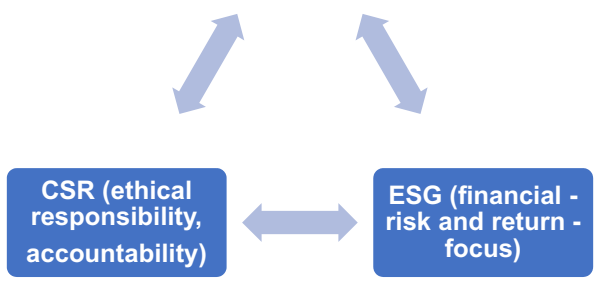

Fig. 1 Sustainability, ESG and CSR - a trilemma

\footnotetext{
4 See e.g., Sjåfjell and Taylor (2015). The 'externality' framing really just confirms that ESG is not coextensive with sustainability. The G in ESG certainly could not be framed as a classic externality as the cost will be borne most directly by shareholders (even if there is some effect on the broader corporate system). See also Agudelo et al. (2019), p 18, linking the sustainable agenda with CSR.

5 See generally Deutsche Bank Group (2012). They show, based on extensive studies, that CSR has essentially evolved into ESG. Not many commentators focus on the transition from CSR to ESG, but note Schanzenbach and Sitkoff (2020), p 388, referring to SRI as having been 'rebranded' as ESG in the late 1990 s and early 2000 s by adding the 'G'. See for a good summary of the differences between ESG investing and sustainable investing https://lib.standardlife.com/library/uk/invp77.pdf (accessed 15 May 2021).
} 


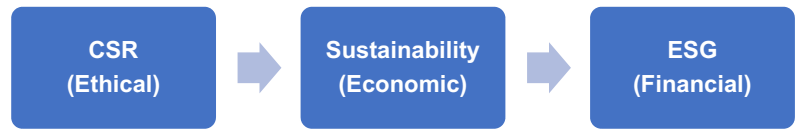

Fig. 2 Timeline

dominant paradigm. We seek to explain the emergence of the financial channel not by reference to explicit choices made by the participants but by reference to underlying legal influences which provided incentives to make the choices that were made. ${ }^{6}$ In Sect. 4 we argue that reverting to an entity model with a stronger CSR focus would be more effective and we sketch out how this might be done.

\section{The Origins and Development of ESG Investing}

We begin by tracing the origins of ESG investing back to earlier developments, in particular CSR and sustainability, and then develop a comparison framework to illustrate the key dimensions in which ESG represented a move away from the foundations of CSR. We focus in particular on the move from CSR to ESG as we see sustainability both as a broader overarching concept (as above) and as a bridge that facilitated the process of financialisation that is represented by ESG. Thus, viewing the trilemma above more as a timeline, it can be represented as follows (see Fig. 2).

\subsection{From CSR to ESG via Sustainability}

Elements of the substantive concerns addressed by CSR — such as the welfare of employees and a broader role of business in terms of social solidarity - can be traced back quite far in history. ${ }^{7}$ However, it was in the 1930 s that CSR in its modern sense began to evolve as ownership diffusion broke the link between ownership and management and focused attention more closely on the purpose for which companies should be managed. ${ }^{8}$ In the 1940 s, broader discussions started to develop about the social responsibilities of companies, as they began to be seen as institutions thinking beyond mere profits, considering the consequences of their actions. ${ }^{9}$ However, it was only in the 1950s that CSR started to take full shape. An influential definition from that time framed CSR (or SR as it was then termed) as follows:

\footnotetext{
${ }^{6}$ Academic discourse around the evolution of ESG would suggest that there was no choice to be made, but we dispute that framing of history, which emerged mainly through the lens of financial economics and without dissent in legal scholarship.

7 Carroll (2008), p 21.

8 Ibid., p 23. This debate can be traced back to Berle and Dodd. See Stout (2002), p 1198, for a discussion of the debate.

9 Agudelo et al. (2019), p 3, referring to Heald (1970). See also Carroll (2008), p 24.
} 
It (SR) refers to the obligations of businessmen to pursue those policies, to make those decisions, or to follow those lines of action which are desirable in terms of the objectives and values of our society. ${ }^{10}$

A later definition of CSR integrated a key insight on the economic foundation of CSR:

The social responsibility of business encompasses the economic, legal, ethical, and discretionary expectations that society has of organisations at a given point in time. $^{11}$

From that perspective, economic viability is something business does for society as well as for itself, by perpetuating the business system. Others then linked CSR more explicitly with ethics and proposed that CSR relates primarily to achieving outcomes from organisational decisions regarding specific issues which have benefits rather than adverse effects for stakeholders. ${ }^{12}$

The 1980s saw a clearer focus on sustainable development and its links to institutional and legal change. ${ }^{13}$ The focus on externalities also linked sustainability more explicitly to mainstream economic thinking than had been the case with CSR, which struggled to gain traction against influential notions of the nature and purpose of the corporate entity. ${ }^{14}$ At this time the role of stakeholders came more clearly to the fore in research ${ }^{15}$ and policy as a mechanism for addressing and resolving externalities associated with sustainable development. The publication of the Brundtland Report in 1987 was a landmark event as it developed guiding principles for sustainable development as it is generally understood today. ${ }^{16}$ It can be linked directly to the emergence of the concept of the 'triple bottom line approach' as a sustainability framework that balances the company's environmental, social and economic impacts (the people, profit and planet dimensions). ${ }^{17}$ This approach became popular in the 1990s as a practical approach to sustainability, linking the ethical dimension of the UN SDGs ${ }^{18}$ more explicitly to the operation of the real economy. Despite the

\footnotetext{
10 Bowen (1953), p 6. See also Hazen (2020), p 5, stating that 'CSR reflects the general principle that companies should be mindful of the public good and not simply be motivated by profit maximization'.

11 Carroll (1979), p 500.

12 E.g., Epstein (1987), p 104. See also Carroll (2008), p 36, referring to this.

13 See Jones (1980), characterising CSR as a decision-making process that influences corporate behaviour. See further Agudelo et al. (2019), p 7.

14 See further Ferrarini (2020), at Part II: the evolution of corporate purpose in economics and finance.

15 See, e.g., Freeman's influential 1984 book 'Strategic management: a stakeholder approach'.

16 The World Commission on Environment and Development (WCED), set up in 1983, published its report entitled 'Our common future'. See https://www.are.admin.ch/are/en/home/sustainable-devel opment/international-cooperation/2030agenda/un-_-milestones-in-sustainable-development/1987--brund tland-report.html (accessed 15 May 2021).

17 First coined by Elkington in 1994. See Elkington (1994), pp 90-100, and Elkington (1999).

18 See Antoncic et al. (2020), p 3: 'SDGs are much broader than the ESGs and focus on good health and well-being, the elimination of poverty, zero hunger, quality education, clean water and sanitation, reduced inequity, as well as the environment and other issues encapsulated in ESGs. Most importantly, the SDGs call for leaving no one behind.'
} 
underlying tensions noted above, that approach also resonated in CSR discourse, ${ }^{19}$ demonstrating the overlap and potential for conflation of the differing concepts in practice.

The 1990s saw the emergence of ESG as a portfolio risk management concept linked to financial performance. ${ }^{20}$ ESG investing is based on the presumption that its constituent factors are material for the risk and return profile of financial investments. $^{21}$ In the equity market, ESG investing is closely aligned with so-called 'responsible investment', ${ }^{22}$ which can extend across the entire spectrum of 'sustainable investment'. ${ }^{23}$ The definition of sustainable investment can vary considerably between stakeholders, ${ }^{24}$ but generally entails applying one of the following strategies: ${ }^{25}$

- Screening of potential investments to enable exclusion of investment in specific sectors, or companies or projects that show poor ESG performance relative to industry peers (negative/exclusionary screening) or companies or projects that do not comply with international norms and standards (norms-based screening);

- ESG integration, whereby ultimate investors may require systematic and explicit inclusion, by investment managers, of environmental, social and governance factors into investment appraisal; ${ }^{26}$

19 See Agudelo et al. (2019), p 9. ESG references elements of CSR with the 'E' focusing on environmental issues and sustainability, the ' $\mathrm{S}$ ' on diversity and inclusion, fair wages and health issues, and the 'G' on governance issues like independent directors, etc. See on this Hazen (2020), p 5. There is also an argument that CSR had never really encompassed the 'social' dimension in the sense developed by critical legal scholars starting with Polanyi. See on this Moncrieff (2015), pp 434-459.

20 See generally Boffo and Patalano (2020), pp 37-40, for a literature review on CSR, SRI and ESG investing.

21 See Amel-Zadeh and Serafeim (2017), addressing the question of what motivates investors to use ESG data. The clear majority of respondents (82\%) suggest that they use ESG information because it is financially material to investment performance. Overall, they found evidence that the use of ESG information has primarily financial rather than ethical motives. (Note large sample of mainstream investors).

22 See https://www.cfainstitute.org/en/research/esg-investing (accessed 15 May 2021) for differences between ESG and SRI. 'ESG investing grew out of investment philosophies such as Socially Responsible Investing (SRI), but there are key differences. Earlier models typically use value judgments and negative screening to decide which companies to invest in. ESG investing and analysis, on the other hand, looks at finding value in companies - not just at supporting a set of values.'

${ }^{23}$ For the spectrum of sustainable investment see https://ec.europa.eu/environment/enveco/sustainable_ finance/pdf/studies/Defining\%20Green\%20in\%20green \%20finance \%20-\%20final\%20report\%20pub lished\%20on\%20eu\%20website.pdf (accessed 15 May 2021).

24 See, e.g., https://lib.standardlife.com/library/uk/invp77.pdf (accessed 15 May 2021) for a stylised summary of the differences between ESG investing and sustainable investing, the former linked to risk and the latter to values.

25 See generally Global Sustainable Investment Alliance Report 2016 at http://www.gsi-alliance.org/wpcontent/uploads/2017/03/GSIR_Review2016.F.pdf (accessed 15 May 2021).

${ }^{26}$ Integration techniques concern the weighing and altering of portfolio components based on ESG information, without banning securities from the start through fundamental, quantitative, smart beta and passive strategies. The UNPRI drafted a practical guide to ESG integration: https://www.unpri.org/listedequity/a-practical-guide-to-esg-integration-for-equity-investing/10.article (accessed 15 May 2021). 
- Shareholder engagement and activism (in some instances promoted by soft law measures such as the Stewardship Code in the UK); ${ }^{27}$

- Sustainability themed investing;

- Impact investing, focusing on measurable positive social or environmental outcomes alongside financial returns. ${ }^{28}$

The move to ESG marked a clear shift away from the earlier model of CSR, where the focus was at the entity level and on the impact of corporate activities on the real world. There was also an increased focus on stakeholder activism, proxy voting and corporate disclosure of ESG policies. Third-party ESG ratings also became available to meet demand. By the turn of the century it was noted that

the criteria of CSR - now referred to here as contemporary CSR — expanded to formally encompass ESG, corporate citizenship and economic responsibility. ${ }^{29}$

At a global level the early 2000s were marked by voluntary CSR initiatives ${ }^{30}$ such as the launch of the United Nations Global Compact. The term ESG featured prominently in 2005 in the 'Who Cares Wins' 31 document, issued by the Global Compact. This study provided recommendations to better integrate environmental, social and governance issues in financial analysis, asset management and securities brokerage. As ESG did not replace CSR, ${ }^{32}$ companies would still report on CSR issues and disclose how they fulfilled certain social obligations and how they balanced these values with profit maximisation, whereas ESG reporting or disclosure became more metrics driven. ${ }^{33}$ The move from CSR to ESG was described as driven by the 'business case' for CSR, ${ }^{34}$ framed in terms of sustainability. This marks a shift from social obligations (underpinned by moral obligation) in CSR to a risk management perspective (e.g., litigation and regulatory risk) in ESG.

27 This is dealt with in detail in Sect.3.2 below where we link the rise of the financial model of ESG investment to the emergence of stewardship as a global force in equity investment.

${ }^{28}$ See further https://www.bridgesfundmanagement.com/wp-content/uploads/2017/08/Bridges-Spect rum-of-Capital-screen.pdf (accessed 15 May 2021), p 3, for a mapping of ESG onto sustainable investing and impact investing respectively. The model breaks ESG down further into mitigation of ESG risk to protect value and progressive ESG policies to enhance value.

29 Deutsche Bank Group (2012), p 24.

30 See Agudelo et al. (2019), p 9.

31 See https://www.ifc.org/wps/wcm/connect/topics_ext_content/ifc_external_corporate_site/sustainabi lity-at-ifc/publications/publications_report_whocareswins_wci_1319579355342 (accessed 15 May 2021) for the document. This seems to be one of the first attempts to operationalise general principles (SDGs, PRI) at the level of investment practice. Endorsing institutions were convinced that a better consideration of environmental, social and governance factors would ultimately contribute to stronger and more resilient investment markets, as well as to the sustainable development of societies.

${ }^{32}$ Hazen (2020), p 5.

${ }^{33}$ CSR reporting seems to be largely superseded by 'sustainability reporting' based on the GRI, see https://www.icas.com/landing/sustainability/practical-tools-and-links/sustainability-reporting (accessed 15 May 2021). It is thus not entirely clear if reporting can help to clarify the distinction between CSR and ESG.

34 See Pollman (2019), p 5. 
Following the Global Financial Crisis (GFC) 2008, the focus on reforming financial regulation provided further momentum both to sustainability as an objective and to ESG as a transmission mechanism. The Task Force on Climate-related Financial Disclosures (TCFD) ${ }^{35}$ Report, issued in 2016, proposed a framework for more effective climate-related disclosures that could promote more informed investment, credit, and insurance underwriting decisions and, in turn, enable stakeholders to understand better the concentrations of carbon-related assets in the financial sector and the financial system's exposures to climate-related risks. The Green Bond Principles (a voluntary set of guidelines for issuing green bonds) were launched in 2018 to promote integrity in the green bond market through guidelines that recommend transparency, disclosure and reporting. ${ }^{36}$

\subsection{Key Attributes of CSR and ESG}

Having outlined the evolution of ESG and its links to CSR, we now identify in Table 1 the key attributes of both approaches to focus more clearly on how they differ. This provides a foundation for the analysis that follows in Sect. 3, which focuses on the manner in which fiduciary duty influenced their development and interaction.

CSR evolved with a clear focus on ethical responsibility and accountability, albeit that the 'business case' for CSR shifted the focus to 'doing well by doing good' as the potential for CSR to improve performance became clearer over time. In contrast, ESG was motivated by concerns over the risk and return implications for investors arising from its three constituents. That difference in approach is fundamental even if ESG and CSR are often assimilated in academic discourse and can overlap in their objectives.

The transmission channel for CSR and ESG differs. CSR developed on the basis that corporate entities and their boards would lead on the framing and implementation of CSR policies. ESG, in contrast, was based on the premise that the supply of finance would be the primary driver of behavioural change and that investors would be the agents of change. Engagement with the board is an important element of ESG, but it is framed in a context that prioritises shareholder interests and marginalises stakeholders.

In the case of CSR, the prioritisation of the board as the transmission channel means that implementation is linked more directly with operations than in the case of ESG, which focuses on the supply of capital. This provides a more detailed and contextual understanding of the operational environment as directors will generally be better informed on those issues than shareholders and better able to integrate and balance CSR issues with other elements of board oversight. Implementation in the

\footnotetext{
35 See https://www.fsb-tcfd.org/ (accessed 15 May 2021).

36 https://www.icmagroup.org/assets/documents/Regulatory/Green-Bonds/Green-Bonds-PrinciplesJune-2018-270520.pdf (accessed 15 May 2021), p 3: 'Green Bonds are any type of bond instrument where the proceeds will be exclusively applied to finance or re-finance, in part or in full, new and/or existing eligible Green Projects (see section 1 Use of Proceeds) and which are aligned with the four core components of the GBP.'
} 


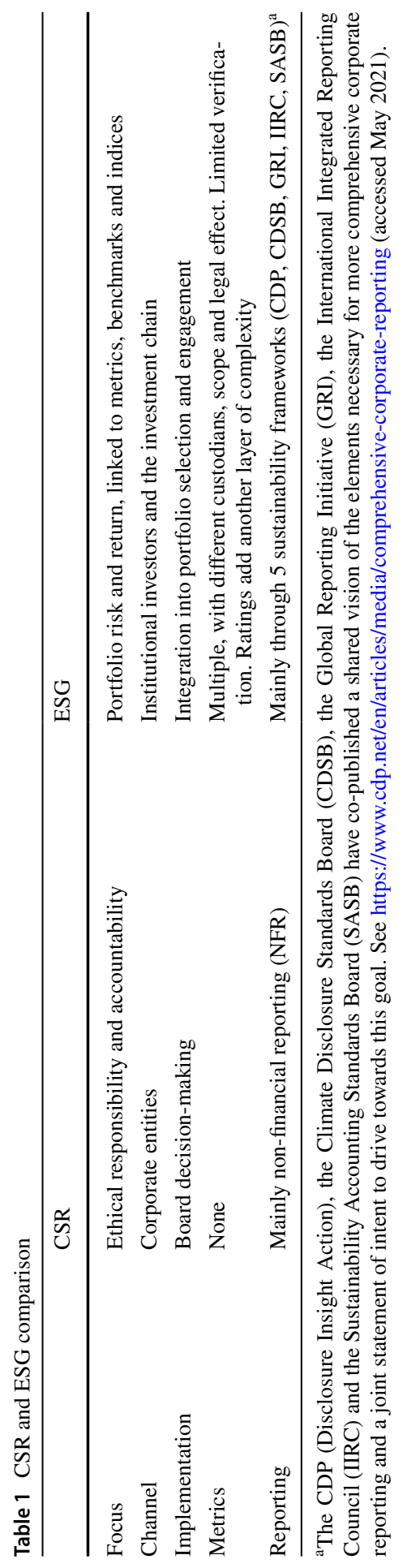


case of ESG is through the investment process, with the launch of the Principles for Responsible Investment (PRI) in 2006 representing a catalyst in the movement towards ESG. ${ }^{37}$

While there is sometimes reference to the 'measurement of CSR' or to metrics relevant to $\mathrm{CSR}^{38}{ }^{38}$ it is far less common compared to ESG. Metrics are usually aimed at ESG factors and relevant to investors when making portfolio choices. To date, the lack of an objective standard ${ }^{39}$ for evaluating the sustainability characteristics of investment projects, products and portfolios has been a major problem and has led to allegations of so-called 'greenwashing'. Recent initiatives such as the EU Taxonomy aim to resolve that issue. ${ }^{40}$

The development of reporting frameworks linked to ESG was a key factor in the movement from CSR to ESG. In the EU, the Non-Financial Reporting Directive $(\text { NFRD })^{41}$ of 2014 focused on corporate disclosure, although it could be viewed as neutral as between CSR and ESG as transmission mechanisms. More broadly, the development of reporting frameworks encompassed a variety of different techniques that combined reliance on private initiatives with public endorsement through regulatory frameworks. ${ }^{42}$

\footnotetext{
${ }_{37}$ See https://www.forbes.com/sites/georgkell/2018/07/11/the-remarkable-rise-of-esg/?sh=7c9612a016 95\#575351571695 (accessed 15 May 2021). It is clear that the UN has been a key player at the global level through the Global Compact, the SDGs and support for the establishment and development of the PRI. The Global Compact is much broader in its focus and membership. But, as demonstrated by the 'Who Cares Wins' Report, referred to earlier, ESG was already in the ascendancy in Global Compact discourse and action by 2005 .

${ }^{38}$ See, for example, https://walterschindler.com/key-csr-metrics-for-sustainability-advisors/ and https:// www.csrtraininginstitute.com/2018/06/19/csr-metrics-measure-and-manage-the-meaningful/(accessed 15 May 2021). The ISO 26000 standards can also be linked to CSR, see https://www.iso.org/iso-26000social-responsibility.html (accessed 15 May 2021). The ISO is an independent, non-governmental international organisation with a membership of 165 national standards bodies. The seven key underlying principles of social responsibility are: accountability, transparency, ethical behaviour, respect for stakeholder interests, the rule of law, international norms of behaviour and human rights.

${ }^{39}$ Lack of objective standards has led to a proliferation of metrics. In a survey conducted in 2019 it was found that the top 10 ESG metrics sought by private equity investors are: ESG policy, assignment of ESG responsibility, the presence of a formal code of ethics, whether there is any litigation ongoing, diversity among employees, board members and management and the net employee composition, the presence of an environmental policy, estimation of the $\mathrm{CO} 2$ footprint, data management processes in place to reduce cybersecurity incidents, as well as health and safety of employees, contractors and the wider value chain. See https://www.finextra.com/blogposting/16750/the-top-10-esg-metrics-privateequity-funds-should-collect (accessed 15 May 2021).

${ }^{40}$ See further $n 125$ below.

${ }^{41}$ Directive 2014/95/EU, amending Directive 2013/34/EU as regards disclosure of non-financial and diversity information by certain large undertakings and groups, [2014] OJ L330/1. See also Esser et al. (2018), pp 729-772, and Esser et al. (2020), pp 209-242. On 21 April 2021 the Commission adopted a proposal for a Corporate Sustainability Reporting Directive (CSRD), which would amend the existing reporting requirements of the NFRD. See https://ec.europa.eu/info/publications/210421-susta inable-finance-communication_en\#csrd (accessed 15 May 2021). For example, it extends the scope to all large companies and all companies listed on regulated markets. It also introduces more detailed reporting requirements, and a requirement to report according to mandatory EU sustainability reporting standards.

42 See Harper Ho and Park (2020) for a survey of global trends in ESG-related reporting, focusing in particular on a systematic characterisation of the different modes of interaction between private standards and public regulation across seven key jurisdictions.
} 
Developments at the global (e.g., GRI, TCFD) ${ }^{43}$ and sectoral levels (e.g., Green Bond Principles) were more clearly aligned with ESG as the dominant paradigm. The EU's 2018 sustainability strategy ${ }^{44}$ set out a clear pathway for developing the financial model of ESG. This was followed through with the 2019 Regulation requiring disclosure from financial firms to inform investors about the sustainability characteristics of their products and portfolios. ${ }^{45}$ The more recent Taxonomy Regulation ${ }^{46}$ has established a framework to evaluate the sustainability characteristics of portfolio companies.

\section{The Financialisation of ESG}

We noted in Sect. 2 that ESG emerged from CSR, which had focused more on corporate responsibility and the role of the board of directors. We will now outline and rationalise the key influences through which ESG became 'financialised'. We start from the high-level observation that the financial model of ESG enabled investors to exert greater control over 'non-financial' issues linked to sustainability as their political salience gathered momentum. It provided an overarching technique for empowering shareholders through various mechanisms linked to the supply of finance. That approach avoided the more direct confrontation between investors and directors that would likely have resulted from pursuing the ESG agenda through an entity model focused more directly on board decision-making. As outlined in Sect. 2, we see the move from CSR to ESG as a transformation in the CSR agenda driven by shareholder interest. That approach brought elements of CSR into the mainstream of shareholder-focused corporate governance and provided a financial logic that linked shareholder influence with fiduciary duties owed to underlying investors. In that sense, the transition from CSR to ESG empowered investors relative to other stakeholders, who were marginalised by comparison with the more traditional CSR approach.

Nevertheless, that observation prompts the question why it was necessary for investors to take control of the ESG agenda rather than leaving CSR implementation to happen at board level, driven by the fiduciary duty owed by directors and subject to the established patterns of accountability. We argue that investors could not rely on corporate fiduciary duty to deliver an appropriate and consistent model of CSR as a result of legal uncertainty and the (increasing) role of other stakeholders in the process of board decision-making. While ESG outcomes (developed through

\footnotetext{
${ }^{43}$ Since 2000 the Global Reporting Initiative provides the world's most widely used standards for sustainability reporting - the GRI Standards. The GRI and the GSSB [they have sole responsibility to set the GRI standards on sustainability reporting, see https://www.globalreporting.org/standards/global-susta inability-standards-board/ (accessed 15 May 2021)] do not check the accuracy or content of the material and its claim, see https://www.globalreporting.org/reportregistration/verifiedreports (accessed 15 May 2021).

${ }^{44}$ See https://ec.europa.eu/environment/sustainable-development/strategy/index_en.htm (accessed 15 May 2021).

${ }^{45}$ See further $\mathrm{n} 125$ below.

${ }^{46}$ Ibid.
} 
the financial channel) might well deliver benefits for stakeholders, they would be indirect in two senses: first, that ESG frames stakeholder protection as a secondorder effect, with priority given to portfolio risk and return; and second, that the real-world effects of ESG might or might not be realised ${ }^{47}$ and would in any case not generally be subject to verification. As we discuss below, shifting the focus from CSR to a financial model of ESG would mitigate those challenges and would in principle move the focus of fiduciary compliance more explicitly into a paradigm focused on financial risk and return. It also represents a preference for ex ante over ex post control mechanisms that was already evident in the soft law evolution of the governance dimension of ESG that started with the Cadbury Code in the UK in $1992 .{ }^{48}$

\subsection{Fiduciary Duty As an Enabler of ESG Investing}

We now focus on how fiduciary duty has been deployed to facilitate the development of a 'financialised' model of ESG investing. We focus first on how fiduciary duty operates differently in the investment chain ('intermediary fiduciary duty') and in the context of board decision-making ('corporate fiduciary duty') and evaluate the consequences of that asymmetry. We then focus on the role of legal uncertainty in the context of both forms of fiduciary duty and its implications for the implementation of a CSR or ESG agenda.

\subsubsection{Asymmetry in Fiduciary Duties}

Two forms of fiduciary duty operate to control the extent to which corporate strategy and operations could focus on CSR or ESG-related outcomes. The first is the duty owed by directors to the company (and in some instances to shareholders). The second is the duty owed by institutional investors to their underlying investors. ${ }^{49}$ It might well be argued that in an ideal world, both forms of fiduciary duty would be aligned so as to reflect the underlying logic that they serve the same purpose. But that perspective conflates the interests of the company and the shareholders in a manner that is inconsistent with the (increasing) role of stakeholders in many systems around the world. Thus, if stakeholders are to have a meaningful role in corporate governance, it seems inevitable that corporate fiduciary duty would have to adjust to accommodate that role. ${ }^{50}$ On the other hand, that adjustment would not carry direct implications for fiduciary duty in the investment chain since that duty

\footnotetext{
47 On the link between ESG portfolio investment techniques and real-world effects see, e.g., Harnett et al. (2020).

48 MacNeil and Esser (2021).

49 That duty is itself a variety of different duties linked to the model of investment. See further MacNeil (2012), chapter 5, for the different models in the UK. For the US see Schanzenbach and Sitkoff (2020). For the purposes of exposition we focus here on the trust model that applies to pension fund trustees.

50 That process was evident in the process of reforming company law in the UK in the early 2000s. See, e.g., s172 of the Companies Act 2006 in the UK, introducing a so-called 'enlightened shareholder value' approach. For discussion of the linkage of this model with shareholder value see Ferrarini (2020), p 24.
} 
is focused primarily on financial risk and return and the relationship between institutional investors and their underlying clients. Thus, the different focus of the two forms of fiduciary duty means they have different objectives and represent different interests. Even if they share an overarching objective of promoting the success of the company, their respective framing of the role of shareholders and stakeholders is quite different and so they are unlikely to operate in unison.

In the light of this asymmetry, it was inevitable that, as the momentum of public policy moved towards sustainability, a choice would have to be made as to which form of fiduciary duty would be prioritised in pursuit of those goals. While elements of each approach (financial or entity) were present under the old CSR model and would likely persist whatever option was selected, it is implicit in the trilemma we present above that a choice of approach would be necessary for a coherent system to evolve. The development of ESG suggests that there was little or no explicit debate around this choice, ${ }^{51}$ but that does not in principle exclude the possibility of choice. In hindsight it seems that the absence of debate is itself evidence of the "financialised' version of ESG having been in the ascendancy from an early stage and having effectively precluded debate around the 'entity' option. It would also tend to suggest that the public policy 'push' towards the financialised version represented by initiatives such as the SDGs and the endorsement of the PRI paid more attention to the 'what' (sustainability) rather than the 'how' (which would likely have led to a more explicit focus on policy choices). And while the GFC might have been expected to generate some pushback against the financialised model, ${ }^{52}$ reflecting the more general pattern of reaction to the global financial crisis, the trend was already well established by then and so less amenable to change. On the contrary, the boost to 'stewardship' provided by the GFC, driven by the perception that it exposed weaknesses in corporate governance, ${ }^{53}$ likely solidified the financialised model by opening up a clearer process for investor activism and engagement and by linking it to 'intermediary' fiduciary duty. ${ }^{54}$

\subsubsection{Legal Uncertainty}

Legal uncertainty is endemic and there are a range of mitigation and risk transfer techniques that attempt to limit its impact in the commercial world. ${ }^{55}$ One of the main concerns is to identify ex ante techniques that can limit the extent to which transactions or decisions would be open to ex post challenge. In the context of ESG, the risk would be that ESG actions, whether strategic or operational decisions taken by a board or portfolio investment decisions taken by an institutional investor, would

\footnotetext{
51 See, e.g., the Freshfields Report 2005 [A legal framework for the integration of environmental, social and governance issues into institutional investment, https://www.unepfi.org/fileadmin/documents/fresh fields_legal_resp_20051123.pdf (accessed 15 May 2021)], which considers only intermediary fiduciary duty.

52 See further Palley (2007).

53 See further MacNeil (2010b), pp 518-520.

54 This led eventually to the development of the first Stewardship Code in the UK in 2010.

55 See generally MacNeil (2009).
} 
be open to challenge by either shareholders or underlying investors (respectively) on the basis that the action was in breach of fiduciary duty. In this Section we outline the parameters of this paradigm and evaluate its likely impact on the development of ESG. We focus on legal uncertainty within national jurisdictions as it is in that context that the legal framework (including fiduciary duty) for institutional investment generally operates, albeit that the major asset management firms operate and set investment policy at a global and regional level. ${ }^{56}$

Legal uncertainty would likely affect both corporate and intermediary fiduciary duty. So the presence of such uncertainty might suggest that neither would be better placed than the other, from the perspective of legal risk, as a conduit for developing ESG. However, three factors suggest otherwise.

- Individual vs collective action In widely dispersed ownership systems, such as the UK and US, which were the main drivers of ESG, individual investors could not effectively influence boards to undertake ESG actions without collaboration. Even if that were legally possible (and it might not always be ${ }^{57}$ ) it would be more costly and less effective than ESG portfolio techniques undertaken unilaterally 'in house' through the techniques identified in Sect. 2.1 above. The portfolio approach would in principle distribute ESG effects more broadly across (listed) companies and would gain traction as points two and three below started to ramp up.

- Mitigation of legal uncertainty through opinions and standards While some academic opinion supported an interpretation of fiduciary duty that would enable boards to implement an 'entity' model of ESG, they tended to be minority views and were not backed by influential legal opinions or powerful NGOs. The opposite was the case for the financialised model and intermediary fiduciary duty, which were supported at an early stage by an influential legal opinion (the Freshfields Report ${ }^{58}$ ) and standards (the PRI) endorsed by the UNEP FI. ${ }^{59}$

- Data The accumulation of evidence on the financial performance of ESG strategies $^{60}$ lent credibility to the financial model of ESG, whereas there was no comparable data to support operational activities undertaken by companies through 'CSR' initiatives. In that sense the available 'evidence' supported the financialised model.

Thus, in terms of the context in which ESG operates, we take the view that legal uncertainty posed less risk to a financial model of ESG than it did to an entity

\footnotetext{
56 The MiFID framework in the EU and the federal system of securities regulation in the US could be viewed as exceptions to the extent that they impose quasi-fiduciary obligations extending beyond state boundaries.

57 See MacNeil (2010a), p 428.

58 See n 51 above. It was issued by the UNEP Finance Initiative in 2005. For background see https:// www.unepfi.org/about/background/ (accessed 15 May 2021).

59 For background on both the PRI and UNEP FI see https://www.unpri.org/pri/about-the-pri (accessed 15 May 2021).

60 See ICGN Guidance on Investor Fiduciary Duties (2018): http://icgn.flpbks.com/icgn-fiduciary_ duties/ (accessed 15 May 2021), p 16, for a concise summary of some key academic studies.
} 
model. Viewed in those terms, investors were better placed to develop the financial model than directors were to develop an entity model of ESG that might have more closely resembled the model of CSR from which ESG emerged. But that high-level perspective glosses over the nature and extent of legal uncertainty in the respective domains and it is to that issue that we now turn.

\subsubsection{Corporate Fiduciary Duty}

Corporate fiduciary duty has attracted relatively more attention from the perspective of corporate purpose and the role of stakeholder interests (the traditional focus of CSR) by comparison with ESG where these issues are relevant but subordinated to the more explicit focus on portfolio risk and return. The key issues have been whether corporate purpose encompasses objectives other than profit maximisation and whether, and if so how, interests other than those of shareholders can legitimately be considered in board decision-making. ${ }^{61}$ Both issues are instrumental in determining the extent to which directors could adopt a sustainable or stakeholderfocused strategy. We therefore turn now to consider whether corporate fiduciary duty would permit directors to adopt such an approach and how legal uncertainty might influence their stance and that of investors. We focus on the UK and the US as the two key jurisdictions in which these issues have been debated.

Turning first to the issue of corporate purpose, we note that in both the US and the UK purpose tends not to be defined explicitly in either statutory corporate law or constitutional documents. ${ }^{62}$ Thus, the default position in both jurisdictions is that it falls to the board of directors to determine corporate purpose in accordance with the standard process of majority decision-making. While in principle that would open up considerable scope for directors to pursue CSR activities, it has been observed that the emergence of a de facto norm of shareholder value maximisation constrained any inclination on the part of boards to act in that way. ${ }^{63}$ While that pattern is evident in both the UK and the US, different influences seem to have been at work and may explain the common outcome in two systems that can be differentiated by reference to the distribution of powers between shareholders and directors, with the US typically characterised as an example of director primacy and the UK as an example of shareholder primacy. ${ }^{64}$

In the UK, it has been argued that this development can be linked to the reforms introduced by the Companies Act 1948, which strengthened the powers of shareholders with regard to the dismissal of directors and facilitated the emergence of

\footnotetext{
${ }^{61}$ These two issues are sometimes treated in a manner whereby one subsumes the other. While there might often be overlap in their implementation, we prefer to view them separately as they are not coextensive.

${ }^{62}$ But for proposals to change that approach see British Academy (2019). Contra that approach see Rock (2020).

63 See Sjåfjell and Taylor (2019), p 47 (note that they use 'shareholder value' to denote a legal norm and 'shareholder primacy' to denote a social norm).

${ }^{64}$ Cabrelli and Esser (2018). Differences in the distribution of powers between shareholders and directors would likely influence the extent to which shareholders could control the evolution and implementation of corporate purpose at the operational level.
} 
hostile takeovers. ${ }^{65}$ Both developments strengthened the role of shareholders and can credibly be viewed as supporting the emergence of a de facto norm of shareholder value maximisation. Another relevant development in the UK was the move to a so-called 'enlightened shareholder value' model of board decision-making as part of the reforms introduced by the Companies Act 2006 (CA 2006). While that reform was widely regarded as a codification of the model of corporate purpose that was already in place, in the sense that shareholders' interests remained in the ascendancy (within the so-called enlightened shareholder value model), ${ }^{66}$ the alternative view of s172 CA 2006 as narrowing the (CA 1985) open-ended formulation of 'the interests of the company' is also credible and supports a view of the CA 2006 as narrowing the discretion of directors with regard to CSR activities. ${ }^{67}$

In the US, the emergence of a de facto norm of shareholder value maximisation has also been noted. ${ }^{68}$ That approach was supported by the Business Roundtable Statement of 1997, which explicitly subordinated the interests of other stakeholders to those of shareholders. ${ }^{69}$ It also attracted support in judicial opinions of the Delaware court and has been argued, in the US context, to be 'the best description of the characteristics of the corporate form in traditional jurisdictions', even in the absence of an explicit statutory rule of shareholder primacy. ${ }^{70}$ There were dissenting views within the academic community, ${ }^{71}$ but they remained a minority view even in that context. However, there is now considerable support for the view that corporate law does not mandate profit maximisation. The Business Roundtable Statement on the Purpose of a Corporation (August 2019) attracted considerable attention as a reversal of its earlier position and followed other high-profile statements supporting the proposition that corporate purpose should be reframed so as to encompass broader stakeholder interests. ${ }^{72}$ Some judicial support for that approach was evident earlier ${ }^{73}$ and has continued in more recent Delaware case law. ${ }^{74}$

\footnotetext{
65 Johnston (2017). The relevant provision was s184 of the Companies Act 1948. Prior to the change in the law, directors could be dismissed only by a special or extraordinary resolution, both of which required a $75 \%$ majority of shareholders voting on the resolution.

${ }^{66}$ See, e.g., Keay (2010).

${ }^{67}$ See Johnston (2017); and Rühmkorf (2015), pp 43-44.

${ }^{68}$ See, e.g., Johnson and Millon (2015), pp 14-15, for a concise history of the evolution of this norm and its link to influential economic theories about the nature and operation of companies.

${ }^{69}$ See Rock (2020).

${ }^{70}$ Ibid., p 9. 'Traditional' jurisdictions in this context refers to states without 'constituency statutes', which expressly permit priority to be given to stakeholder interests in some instances. See further Bebchuk and Tallarita (2020), presenting empirical evidence that directors have generally not used those powers to protect stakeholder interests (in takeover situations).

${ }^{71}$ See, e.g., Stout (2012). For a concise summary of the book by the author see https://scholarship.law. cornell.edu/cgi/viewcontent.cgi?article=2311\&context=facpub (accessed 15 May 2021).

${ }^{72}$ Rock (2020), pp 3-5.

73 As one commentator observed in respect of the 2015 Supreme Court decision in the Hobby Lobby case: 'In Hobby Lobby, the Supreme Court did not describe state law as unsettled or uncertain on the issue of corporate purpose; instead, it had no difficulty concluding that state corporate law simply does not require profit maximization.' Burwell v. Hobby Lobby Stores, Inc., 134 S. Ct. 2751 (2014). See Johnson and Millon (2015).

${ }^{74}$ See further Fisch and Davidoff Solomon (2021), p 22: '[...] recent Delaware Caremark decisions suggest that insufficient attention to stakeholder interests may itself be legally actionable [...] In the wake of Marchand, Delaware courts have seen an uptick in Caremark claims, and corporations have increased their focus on risk assessment and compliance.'
} 


\subsection{4 'Intermediary' Fiduciary Duty}

It follows from the general principle that the content of fiduciary duty can be adjusted by contract that investment mandates can modify the default model of fiduciary duty owed by asset managers to underlying investors. ${ }^{75}$ The growth of SRI and ethical funds had already foreshadowed this development, as the explicit identification of such objectives in the fund agreements clearly adjusted fiduciary duties so that those objectives could be achieved, even if the outcome might be to forego other more lucrative investment opportunities.

However, implementation of an ESG focus more broadly across mainstream funds managed by a fiduciary asset manager presents a different issue as in those circumstances what is proposed is a change from past practice in terms of portfolio selection and engagement without any explicit change to fiduciary duty. To the extent that the change in practice aligns with fiduciary duty, there would be no problem. However, if the change in practice conflicted with fiduciary duty, a general move towards ESG would be more problematic. Thus, a key issue in the evolution of ESG, and which retains at least some salience currently, is whether a general move towards ESG on the part of asset managers corresponds with fiduciary duty. We trace that debate from its early origins in the Freshfields Report through to more recent developments and evaluate their significance.

In the investment chain, in both the UK and the US, fiduciary duty was conventionally understood as focused on financial return. ${ }^{76}$ While there are differences in the context in which common law fiduciary duty is applied by reference to different types of fund and specific statutory provisions, the core of the duty can be split into two elements: a duty of care which relates to the professional standards applicable to portfolio strategy and investment selection; and a duty of loyalty which relates to the protection of the interests of the beneficiaries of the fund. ${ }^{77}$ The conventional interpretation emphasises the overarching priority of financial return in the context of the duty of care and close attention to the interests of the beneficiaries in the duty of loyalty. Thus, it could be said that, within those parameters, the conventional position already permitted reference to ESG factors, albeit that in the early stage of the development of ESG investment there was less evidence of past investment performance and less clear calibration of future risks than would be the case later. We refer below to this model of fiduciary duty as the permissive model and contrast it with the emerging 'mandatory' model, which posits that it would be a breach of

\footnotetext{
$\overline{75}$ See generally MacNeil (2012), p 445, discussing relevant case law in the context of UK financial markets.

${ }^{76}$ See ICGN Guidance on Investor Fiduciary Duties (2018), http://icgn.flpbks.com/icgn-fiduciary_ duties/ (accessed 15 May 2021), p 16: 'Historically, concepts of fiduciary duty have focused on maximising investment returns without due consideration of environmental, social and governance (ESG) factors.'

${ }^{77}$ See further with respect to the UK, MacNeil (2012), chapter 5 'Institutional Investment'; and with regard to the US, Schanzenbach and Sitkoff (2020).
} 
fiduciary duty to ignore ESG factors in investment practice regardless of their financial materiality. ${ }^{78}$

There is relatively little case law in the UK on intermediary fiduciary duty and it has in any event not kept pace with developments in investment practice such as ESG. ${ }^{79}$ While that situation inevitably cast some doubt over the precise contours of the duty, contractual solutions in the form of investment mandates adopting a variety of ESG strategies provided a partial solution. So too did the growing evidence of ESG outperformance, ${ }^{80}$ which over time limited the legal risk associated with ESG integration, especially for pension funds where the time horizon is generally longer. More recently the growth of so-called 'impact investing' has extended the spectrum of investment to include investments made with the intention to generate positive, measurable social and environmental impact alongside a financial return. The priority given to impact in this model distinguishes it from ESG integration and raises related issues for fiduciary investors that have to date been less clearly addressed. ${ }^{81}$

The conventional approach was challenged by the Freshfields Report in $2005 .^{82}$ Its conclusion was essentially that it was permissible for a fiduciary to incorporate ESG factors into investment decision-making in both the US and the UK, albeit that financial return would normally remain the overriding objective (unless modified by the investment mandate or the clear preference of the beneficiaries). ${ }^{83}$ It was observed also that it was

arguable that ESG considerations must be integrated into an investment decision where a consensus (express or in certain circumstances implied) amongst the beneficiaries mandates a particular investment strategy. ${ }^{84}$

That approach underpinned the development of the PRI in 2006 and supported the subsequent expansion of ESG investing. By 2015, and with the benefit of increasing evidence of the financial outperformance of ESG investing, the PRI had adopted a

\footnotetext{
${ }^{78}$ It is probably true to observe that the distinction may be less significant in practice than in theory, as fiduciary duty focuses more on process and less on outcomes (meaning that due consideration and no more might be given to ESG factors), but it nevertheless serves a useful purpose to demarcate the two opposing views which have influenced the development of hard and soft law.

79 See further Law Commission Consultation on Fiduciary Duties of Investment Intermediaries (2014), https://www.lawcom.gov.uk/project/fiduciary-duties-of-investment-intermediaries/ (accessed 15 May 2021).

80 See, e.g., Boffo and Patalano (2020); Antoncic et al. (2020).

81 But see in this regard the Impact Investing Institute (October 2020). This legal opinion crafts a nuanced case for impact investing for fiduciary investors.

82 See the Freshfields Report (n 51 above), p 6, where the key question to be addressed by the Report reflects the dominance of financial factors in prevailing investment practice: 'Is the integration of environmental, social and governance issues into investment policy (including asset allocation, portfolio construction and stock-picking or bond-picking) voluntarily permitted, legally required or hampered by law and regulation; primarily as regards public and private pension funds, secondarily as regards insurance company reserves and mutual funds?'

83 Ibid., p 12. The Report was less categorical with regard to the position of other jurisdictions that were included in the survey of relevant laws.

84 Ibid., p 13.
} 
more robust position, arguing that fiduciary investors were required to consider ESG factors and that policymakers and regulators should act to clarify the position. ${ }^{85}$

While the progressive Freshfields stance gained traction in the soft law space in which guidance such as the PRI operates, it was less influential for the interpretation of hard law. In its 2014 consultation the Law Commission adopted a more conventional formulation of intermediary fiduciary duty:

The report concludes that trustees should take into account factors which are financially material to the performance of an investment. Where trustees think ethical or environmental, social or governance (ESG) issues are financially material they should take them into account. ${ }^{86}$

That approach seems to align with the permissive view of ESG factors in investment practice but stopped short of the mandatory view espoused by the PRI. A similar position was adopted by the influential International Corporate Governance Network (ICGN), whose guidance on model terms stated:

The term ESG is used here to mean material and relevant investment risks and opportunities for asset owners with long-term horizons. ${ }^{87}$

Similarly, Principle 7 of the UK Stewardship Code ${ }^{88}$ focuses on integration of material ESG factors. Thus, while the progressive view has been influential, it is by no means the dominant view, especially within the regulatory and investment community, where alignment with the more conventional view formulated by the Law Commission seems to be to the fore.

Turning now to the US, it was noted in the Freshfields Report in 2005 that EU asset managers were ahead of US counterparts in adopting ESG integration strategies. Legal uncertainty likely remained a more prominent issue in the US, as evidenced by a 2019 study commenting on the use of ESG information by investors. ${ }^{89}$ That observation nevertheless masks progress towards recognition of ESG as consistent with fiduciary duty in the US. ${ }^{90}$ While that shift falls short of the more

\footnotetext{
${ }^{85}$ See PRI, Fiduciary duty in the twenty-first century, https://perma.cc/JK62-72VZ (accessed 15 May 2021), pp 9 and 10.

${ }^{86}$ Law Commission Consultation on Fiduciary Duties of Investment Intermediaries (2014), https://www. lawcom.gov.uk/project/fiduciary-duties-of-investment-intermediaries/ (accessed 15 May 2021).

87 ICGN Model Mandate Initiative. Model contract terms between asset owners and their fund managers, https://d3n8a8pro7vhmx.cloudfront.net/intentionalendowments/pages/27/attachments/original/14207 77456/ICGN_Model_Mandate_Initiative.pdf?1420777456 (accessed 15 May 2021). The ICGN Global Stewardship Principles refer to ESG factors as 'core components of fiduciary duty' but it seems clear from the model terms that ICGN adopts a financial materiality threshold for consideration of ESG factors.

${ }^{88}$ See further https://www.frc.org.uk/investors/uk-stewardship-code (accessed 15 May 2021). The custodian of the Stewardship Code is the Financial Reporting Council, which exercises oversight of financial reporting and audit in the UK.

${ }^{89}$ See Amel-Zadeh and Serafeim (2017), p 87: 'We find a higher proportion of US compared to European investors (22\% vs $4 \%$ ) thinking that the information is not material for investment purposes and that using the information would violate their fiduciary duty (22\% vs $8 \%)$.'

90 Schanzenbach and Sitkoff (2020), commenting at p 382: '[...] ESG investing is permissible under American trust fiduciary law if two conditions are satisfied: (1) the trustee reasonably concludes that
} 
assertive stance of the PRI that ESG investing is and ought to be mandatory, the prospects for the PRI's position has recently been strengthened by the stance of the Regenerative Crisis Response Committee, which recommends more explicit recognition of ESG standards by relevant US regulators as a means for the US to 'leapfrog' the measures adopted in other global markets such as the UK. ${ }^{91}$ Nevertheless, as evidenced by the 2019 initiative of UNEP FI and the PRI to clarify the legal framework, ${ }^{92}$ there can be little doubt that there remains some uncertainty in the US and globally over the extent to which ESG factors can be integrated into investment decision-making.

\subsubsection{Fiduciary Duty As a Driver of the Financial Model of ESG}

Having identified and evaluated the key elements of fiduciary duty that facilitated the emergence of the financial model, we now integrate them into a more concise statement of our position and attempt to place them in the broader context of the evolution from CSR to ESG.

Fiduciary duty is the key driver of the development of ESG but to date the significance of two aspects of fiduciary duty has been largely ignored. The first is the asymmetry between fiduciary duty in the investment chain and in corporate decision-making respectively. We argue that this asymmetry led to an implicit choice between the financial and corporate (entity) models of ESG because the two forms of fiduciary duty operate in ways that are inconsistent. An important aspect of that choice was the effect of legal uncertainty surrounding the operation of fiduciary duty in each model. We argue that legal uncertainty posed greater risks for the entity model by comparison with the financial model. Furthermore, we observe that while legal uncertainty was clearly present in both models over the timeline of development of ESG, mitigating actions supported the financial model and thereby strengthened its relative attractiveness.

From a broader perspective, several other influences supported the choice of the financial model. In the first instance, the financial model provided a global conduit for investors to influence board decision-making indirectly through the supply of finance, irrespective of the relative distribution of power between the shareholders and the board. That model could likely be mobilised more rapidly and effectively

\footnotetext{
Footnote 90 (continued)

ESG investing will benefit the beneficiary directly by improving risk-adjusted return; and (2) the trustee's exclusive motive for ESG investing is to obtain this direct benefit.'

91 See Regenerative Crisis Response Committee, Fact Sheet: Modernizing Fiduciary Duty, https://regen erativecrisisresponsecommittee.org/recentwork/factsheet-fiduciaryduty (accessed 15 May 2021). See also the news release from the US Dept. of Labour of 10 March 2021 (https://www.dol.gov/newsroom/relea ses/ebsa/ebsa20210310 (accessed 15 May 2021)) indicating that it would not enforce recently published final rules on 'Financial Factors in Selecting Plan Investments' and 'Fiduciary Duties Regarding Proxy Voting and Shareholder Rights'. The rationale was that these rules created disproportionate risks for ESG investing by pension funds by requiring investment based solely on 'pecuniary factors'.

92 See UNEP, PRI and Generation Foundation, 'A legal framework for impact', https://www.unepfi.org/ wordpress/wp-content/uploads/2019/02/Legal-Framework-for-Impact_UNEPFI_PRI_Generation.pdf (accessed 15 May 2021).
} 
at a global level than one which had to pay greater attention to substantial differences in national legal regimes in terms of the respective powers of shareholders and directors. ${ }^{93}$ Secondly, the financial channel provided exclusive access for shareholders to corporate decision-making, with stakeholders being marginalised, even if they were indirectly the beneficiaries of ESG actions. Thirdly, the entity model would have run counter to the prevailing ethos in the public and private initiatives through which the transformation of CSR into ESG was underway. That ethos focused on the global aspects of sustainability, stressed the common challenges that were faced and the shared responsibility for developing solutions. Finally, innovation in the supply of ESG-themed funds tapped into increased awareness of and demand for 'green' investments without the need to resolve the legal uncertainty issues discussed above. Against that background, an emerging global asset management industry was well placed to align sustainability with its own globalised financial ambitions by taking control of ESG in a way that was quite different from the way it had largely distanced itself from CSR in the past. Proponents of the financial model of ESG could rightly claim that it facilitated the survival and evolution of elements of CSR into a proposition better aligned with global capital markets, but such 'alchemy' as was achieved was only partial and omitted key elements of the older tradition.

\subsection{Stewardship As an Accelerator of ESG}

We link the rise of the financial model of ESG investment to the emergence of stewardship as a global force in equity investment. In its modern form, supported by self-regulatory codes, stewardship emerged after the turn of the millennium and was linked to evolution in the investment ownership chain driven by the move to institutional ownership and centralisation and digitalisation in the custody arrangements for investments. These influences distanced institutional investors from their clients and raised concern over the extent to which intermediation might compromise compliance with intermediary fiduciary duty. ${ }^{94}$ It was against that background that stewardship codes emerged around the world ${ }^{95}$ and, as we argue below, provided a conduit for the financial model of ESG investment to consolidate its dominance.

In its early phase of development, the stewardship movement was driven by concerns over short-termism in the practice of investment management and divergence in the interests of managers from those of underlying investors. ${ }^{96}$ The perception was that liquid markets often made the 'exit' option relatively easy compared with 'voice', which might well offer better returns over the longer term. Alongside those concerns, the rapid growth in low-cost 'passive' investment strategies suggested that

\footnotetext{
93 See further Cabrelli and Esser (2018).

94 See further The Myners Review of Institutional Investment for HM Treasury (2000), https://silo.tips/ download/the-myners-review-of-institutional-investment (accessed 15 May 2021).

95 See generally Katelouzou and Siems (2020).

96 See the Myners Review, n 94 above; and 'A review of corporate governance in UK banks and other financial industry entities', July 2009, aka 'The Walker Review', https://webarchive.nationalarchives.gov. uk/+/http:/www.hm-treasury.gov.uk/d/walker_review_261109.pdf (accessed 15 May 2021).
} 
the relatively high cost of engagement with portfolio companies and the potential for 'free-riding' might well limit its attraction as a proposition for enhancing returns. Against that background, there was considerable potential for sustainability to gain traction through its focus on the long term and its reconfiguration (in terms of ESG) as a technique for financial risk mitigation.

A key factor enabling stewardship to act as an accelerator for the financial model of ESG was alignment with the shareholder primacy model of corporate governance. As already noted, the transition from CSR to ESG had largely marginalised stakeholder interests and this trend was continued by the rise in stewardship codes. ${ }^{97}$ In the UK Stewardship Code, for example, sustainable benefits are framed as the outcome of a stewardship process that creates long-term value for investors. ${ }^{98}$ Thus, the role of sustainability is subordinated to shareholder value and its relationship with ESG is surprisingly not clarified, despite the rapid growth of ESG assets under management among signatories ahead of the 2020 revision of the Code.

Stewardship codes have also supported the financial model of ESG investing by linking stewardship obligations to ESG and intermediary fiduciary duty. That link is more evident in general references to ESG factors than it is to explicit recognition of ESG factors as part of institutional investors' fiduciary responsibilities. For example, a survey of 25 codes found that 21 refer at least once to ESG factors. ${ }^{99}$ Despite being the originator of the stewardship movement, the UK Code is relatively weak in its linkage of stewardship with fiduciary duty. The UK Stewardship Code does not link engagement with fiduciary duty-indeed the 2020 Code makes no mention of fiduciary duty. Thus, although engagement is one of the main ESG strategies, the Code avoids framing even a soft law requirement for engagement. ${ }^{100}$ Thus, the inference seems to be that the UK has a weaker causal link running between fiduciary duty, ESG and stewardship than some other countries. But at the global level, and perhaps most importantly in jurisdictions where shareholder rights are weaker than in the UK, ${ }^{101}$ stewardship codes likely did provide some impetus to shareholder

\footnotetext{
97 The inevitability of that outcome is noted by Chiu and Katelouzou (2018), p 73, who go on to argue that the marginalisation of public interest in the UK system of shareholder-centric stewardship suggests that more regulation is required of the intermediary role in in the investment chain.

98 Principle 1 of the 2020 Code. See also Chiu and Katelouzou (2018), p 85, commenting on the evolution of the UK Stewardship Code from its previous incarnation: 'The Code [the superseded Institutional Shareholders' Code] has been rebranded into a "Stewardship" code, framing shareholder engagement into an exercise of responsible ownership which connects the private interests of institutions to their perceived socially important role.'

99 See Katelouzou and Klettner (2020). The strongest stance is in South Africa (Code for Responsible Investing 2011 in SA) building on the PRI, followed by Australia. The survey also found frequent references to fiduciary duty in stewardship codes, prompting reference to the capacity of stewardship codes to 'interpret and extend' hard law, albeit that '[...] from the nineteen codes that explicitly link stewardship practices to the fulfilment of investors' legal duties, only four codes (i.e. Brazil 2016, ICGN 2016, Kenya 2017 and Thailand 2017) clearly regard the consideration of ESG factors as part of institutional investors' fiduciary responsibility' (Katelouzou and Klettner (2020), p 25).

100 In contrast, the 2010 version of the Code had recognised that activism is a strategy that should be considered by institutional investors in order to discharge their fiduciary obligations to end-beneficiaries. See MacNeil (2010a), p 425.

101 See MacNeil (2010b), pp 421-423, for a concise summary of UK shareholder rights in this context.
} 
engagement and activism, especially as global investment strategies became more common from the turn of the millennium. In the EU, the Shareholder Rights Directive (SRD) II supported that trend by requiring disclosure by asset managers to clients and public reporting by the client on the use of ESG factors, or not, according to the 'comply or explain' model. ${ }^{102}$

\section{An Entity Model of ESG Investing}

We now turn to sketching out the contours of an entity model of ESG investing. We frame it within the contours of the standard company form while recognising at the same time that entity design and selection present an alternative approach, especially with recent developments in entity design with a social and stakeholder focus. ${ }^{103}$ Although we specify the model by reference to ESG, what we really have in mind is closer to a CSR model, in terms of the criteria referenced in Section 2 and Table 1 above. An entity model of ESG would be a step in that direction. It would alter not just the transmission channel for ESG but also the substance and operation of ESG principles.

The underlying premise of the financial model is that there is no clear or consistent obligation to implement sustainability at the entity/operational level. Once that constraint is overcome, it is no longer necessary to use the financial channel to drive ESG as all funding can only be channelled to entities that comply with such an obligation. Thus, the financial model in its current form is an interim market-driven solution, which responds to legal risk and is a precursor to a more systematic approach at the entity level. This approach would also mitigate greenwashing as it would remain a risk mainly at the corporate level and not have two potential layers as per the financial model (i.e., greenwashing by companies and financial firms respectively) (see Table 2).

Our model combines law reform with a residual role for soft law (especially governance and stewardship codes) and voluntary action (such as purpose provisions in articles and 'say on purpose'). Framing the latter two in a residual role (with priority given to law reform) mitigates the shareholder primacy model embedded in many systems of corporate law, which would stand in the way of voluntary action in some instances, as shareholders would be able to block change. In other words, voluntary change within the current system should not be ignored as the rise of the financial model of ESG has shown that it is feasible. We sketch the contours of the model in the same terms we employed to trace the transition from CSR to ESG in Table 1 above so as to extend the trajectory of evolution in a consistent manner to the next stage.

\footnotetext{
102 For a concise summary of these ESG-related aspects of SRD II see https://www.lexology.com/libra ry/detail.aspx?g=6dd6ed8f-7c90-49a4-bf87-27e229560325\&utm_source=Lexology+Daily+Newsfeed\& utm_medium=HTML+email+-+Body+-+General+section\&utm_campaign=Lexology + subscriber+ daily+feed\&utm_content=Lexology+Daily+Newsfeed+2020-11-18\&utm_term $\equiv$ (accessed 15 May 2021).

103 See Brakman Reiser (2012-2013).
} 


\subsection{Focus}

Following our approach in distinguishing CSR from ESG in Sect. 2.2 above, we use the term 'focus' here to refer to the overarching objectives and key beneficiaries that are embedded in the respective models of ESG. Our proposed entity model would shift the focus of ESG investing to stakeholders. That would occur primarily through the introduction of a duty of due diligence, supported by a stakeholder board committee. We discuss both issues in more detail in the following Section. We view the focus on stakeholder empowerment primarily as a mechanism to drive internalisation of externalities. While regulation (e.g., in the form of carbon taxes or import duties) might also drive that process, we see a role for stakeholder empowerment to contribute in terms of capturing the organisational and operational aspects of a business in more detail than would typically be possible through regulation.

The focus of the financial model on the investment chain as the primary driver of ESG subordinates the accountability of the board of directors of companies for the operational aspects of ESG. Boards are less likely to lead on ESG development in a situation where they lack discretion because of the mandate that is transmitted through the investment chain or where there is no direct consequence because of inaction. That in turn is likely to limit their capacity and inclination to drive internalisation of externalities at the operating level to achieve real-world change. In contrast, the entity model locates accountability more clearly with the board alongside other forms of strategic decision-making. Furthermore, it offers potential to integrate ESG more effectively with remuneration and incentives. Currently, remuneration plans do not necessarily promote sustainable value creation for companies. Various proposals have been made to rectify that situation and ESG-linked remuneration seems likely to feature in the legislative proposal to be brought forward by the European Commission in summer 2021. ${ }^{104}$

\subsection{Channel}

Shifting to an entity model of ESG would align with a prominent role for a duty of due diligence. Such a duty can be framed as a business process (a procedural requirement) or a standard of conduct (where the focus is on discharging obligations that go beyond internal process) or some combination of both. ${ }^{105}$ This provides a more focused and precise alternative to adjustment of directors' duties to encompass sustainability, which might well be frustrated by pressures such as the established norm

\footnotetext{
104 See the EY Study on directors' duties and sustainable corporate governance, final report (July 2020), https://op.europa.eu/en/publication-detail/-/publication/e47928a2-d20b-11ea-adf7-01aa75ed71a1/langu age-en (accessed 15 May 2021). It proposes both soft and hard law forms of linkage. For a hard law model linking a specified percentage of remuneration to ESG see Johnston et al. (2019).

105 Bonnitcha and McCorquodale (2017). Their focus is on human rights, but it is equally applicable in the context of sustainability more generally. See further Martin-Ortega (2013), p 56: 'Therefore, human rights due diligence [...] switches the focus from the risk to the corporation to that posed by those affected by its activities. It goes beyond the corporate governance standard of risk management to include a whole range of purposes: to identify, prevent, mitigate and account for human rights impact.'
} 


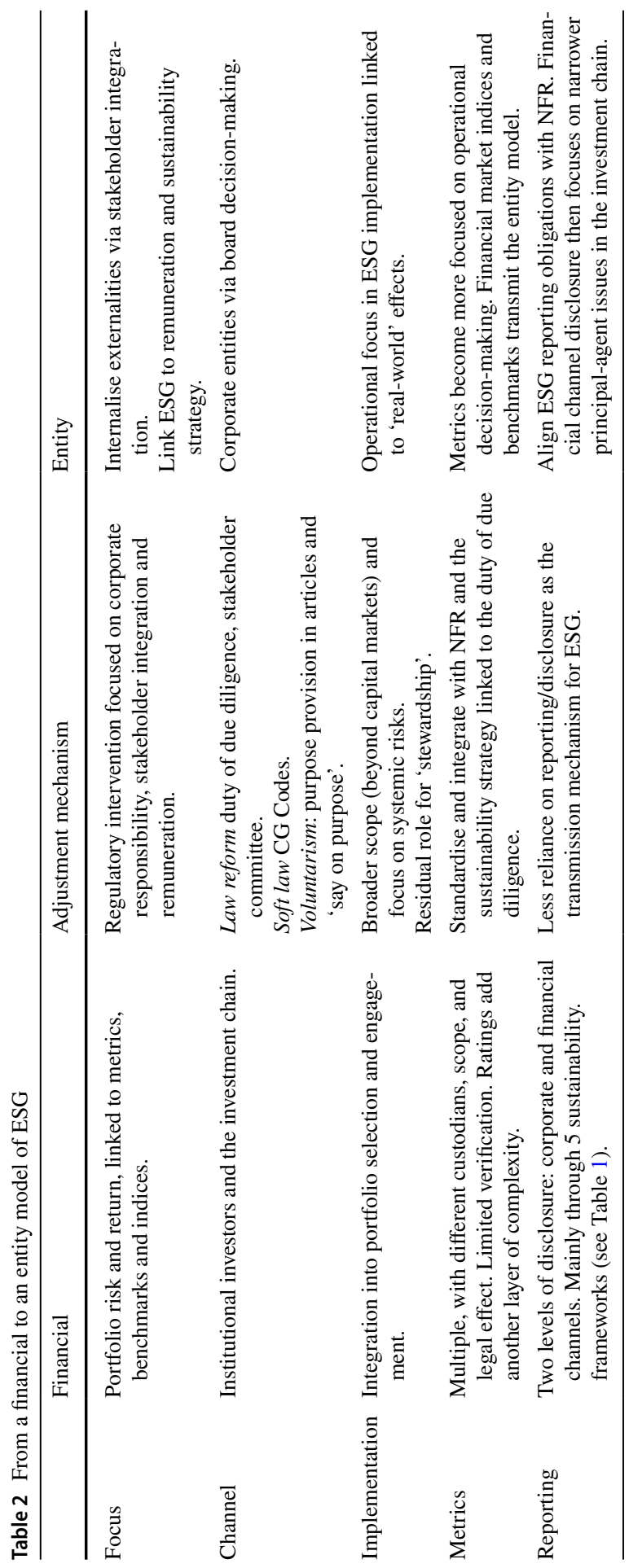


of shareholder primacy. ${ }^{106}$ France has introduced substantive due diligence obligations (going further than mere reporting) with a law known as the duty of vigilance ('le devoir de vigilance') where corporations are required to take reasonable care in identifying and preventing risks to human rights, fundamental freedoms, health and safety, and the environment. ${ }^{107}$ The EU's recent study on sustainable corporate governance proposed a due diligence obligation and it seems likely that this will be included in a legislative proposal by mid-2021. ${ }^{108}$ While the focus has been primarily on due diligence with respect to human rights and environmental obligations (building on models already in place at the global and EU levels), the European Parliament's proposal also includes governance ${ }^{109}$ within its remit and covers within its scope all undertakings governed by the law of a Member State or established within the EU.

A duty of due diligence would give more prominence to the role of board decision-making in ensuring sustainable outcomes. We see this as having several advantages over the prevailing financial model of ESG. First, by placing the process closer to the operations of the company there is likely to be better contextual understanding of how they can adapt to a more sustainable model. ${ }^{110}$ Second, a mandatory duty provides a mechanism whereby any tendency to prioritise shareholder interest over sustainability can be overcome. Third, a more prominent role for board decisionmaking opens the potential for more effective stakeholder integration into the process by comparison with the financialised model of ESG. Our earlier suggestion of a

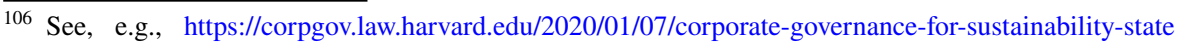
ment/ (accessed 15 May 2021). Examples of this approach can be seen in recent developments in France, the Netherlands and Switzerland, which have all introduced versions of such a duty. See p $104 \mathrm{ff}$ of the EY study (n 104 above) for more details.

107 See http://www.bhrinlaw.org/frenchcorporatedutylaw_articles.pdf (accessed 15 May 2021). The duty comprises three obligations: establishing a vigilance plan with measures to identify risks; implementation of the plan; and reporting on the effective implementation of the plan. Civil liability for breach of the plan is based on the general principles of tort.

108 See further the EY Study (n 104 above). On 29 April 2020, the European Commissioner for Justice, Didier Reynders, announced that the Commission committed to introducing rules for mandatory corporate environmental and human rights due diligence, as part of a Sustainable Corporate Governance initiative. The announcement was made during a high-level online event hosted by the European Parliament's Responsible Business Conduct Working Group, during which the Commissioner presented the findings of the Commission study on options for regulating due diligence requirements: see https://www.busin ess-humanrights.org/en/latest-news/eu-commissioner-for-justice-commits-to-legislation-on-mandatorydue-diligence-for-companies/ (accessed 15 May 2021). More recently, the European Parliament's Legal Affairs Committee has supported this initiative: see https://www.europarl.europa.eu/news/en/press-room/ 20210122IPR96215/meps-hold-companies-accountable-for-harm-caused-to-people-and-planet (accessed 15 May 2021).

109 We note in principle that the inclusion of governance carries implications for the operation of 'comply or explain' codes of corporate governance in the EU, as a duty of due diligence would represent a form of migration from soft to hard law in this context. See generally MacNeil and Esser (2021).

110 Compliance with the duty of due diligence would potentially also provide a degree of legal certainty to the board in the context of legal challenges against states and companies linked to sustainability: see, e.g., https://www.jus.uio.no/english/research/areas/companies/blog/companies-markets-and-sustainabi lity/2021/mandatory-sustainability-due-diligence--sjafjell-mahonen.html (accessed 15 May 2021).
} 
stakeholder board committee might well play a role here to fulfil an oversight function or even be required to sign off on the due diligence. ${ }^{111}$

However, we are conscious that challenges remain regarding setting a basis for liability and enforcement of such a duty, especially if it is to be framed to encompass standards as well as a procedural dimension. Over time, the use of metrics and targets might provide a basis for liability for breach of standards, but even so, private enforcement (for example, via the derivative action in the UK) would likely remain problematic and so an element of public enforcement would be worth considering. ${ }^{112}$ However, for the immediate future we would favour a model for the UK that adopted a procedural approach linked to reporting. We see the key element of due diligence as being the integration of stakeholder interests and perspectives in board decision-making. In line with the European Parliament's proposal, a stakeholder board committee seems a sensible approach and could be linked in the UK context with a requirement to include the operation of the committee in the s172 statements that listed companies are required to produce. ${ }^{113}$ Thus, unlike the European proposal, our model would not make substantive adjustments to directors' duties nor change the pattern of enforcement to provide legal remedies to stakeholders against directors, albeit that we do see merit in the grievance procedure in the European proposal (which could be based on a collective or sectoral model) for resolving disputes between stakeholders and companies. ${ }^{114}$

Voluntary action could also play a role in moving towards an entity model. An important strand in the current debate is the role of corporate purpose. ${ }^{115}$ This has

\footnotetext{
111 See Esser and MacNeil (2019), p 218, and MacNeil and Esser (2020), p 12. The South African social and ethics committee (see s 72(4) of the South African Companies Act 2008 and Regulation 43) is, in principle, a good initiative to give effect to the interests of stakeholders. The role of directors is to develop and implement a sustainable business model for the company that provides a competitive return to shareholders. When doing this, they need to have regard to the interests of various stakeholders. By having a committee that addresses the board on issues that are relevant when making business decisions, directors should be in a better position to make the best decision for the company. However, there are various shortcomings and uncertainties with this committee. Its terms of reference are not clear enough. There is uncertainty as to whether this is a board committee or a company committee and this has various implications. The tension that can be created between the board and the shareholders is also problematic based on the fact that the committee should report back to the shareholders. Despite this, the aims and functions of the social and ethics committee should at least sensitise the board in respect of the interests and importance of other stakeholders. See generally on this committee Esser and MacNeil (2019) and Esser and Delport (2017a) and (2017b).

112 See generally the EY study, at n 104 above, for a discussion of enforcement options. It is also recommended in the Corporate Governance for Sustainability Statement-https://corpgov.law.harvard.edu/ 2020/01/07/corporate-governance-for-sustainability-statement/ (accessed 15 May 2021) — that a national regulatory body should be empowered to bring proceedings against the executive directors where the proposed sustainability strategy was not implemented and that resulted in harm to third parties.

113 See further Chalaczkiewicz-Ladna et al. (2021).

114 For more trenchant resistance to the EU model see the ICGN response to the EU sustainable corporate governance consultation at https://www.icgn.org/sites/default/files/3.\%20ICGN\%20response\% 20to\%20Sustainable\%20Governance\%20EU\%20Consultation\%202021.pdf (accessed 15 May 2021). Our model differs in two key dimensions: viewing stakeholder integration into board-decision making as a fundamental element of sustainability; and viewing 'comply or explain' governance codes as an inadequate basis for the integration of fundamental elements of governance structure and process.

115 See generally Ferrarini (2020).
} 
been approached in different ways but a common thread is that companies should define their purpose so as to integrate more explicitly the public interest in their activities and thereby to move beyond a model that prioritises shareholder interests. ${ }^{116}$ Voting by shareholders on corporate policy has been suggested as a way to facilitate a broader concept of 'shareholder welfare' that captures the long-term benefits from integrating stakeholder interests. ${ }^{117}$ Another, more direct, possibility is to deal with stakeholder issues and sustainability through a purpose provision by embedding it into the governance structure either explicitly ${ }^{118}$ or implicitly. ${ }^{119}$ It has been suggested that a purpose statement, as being part of the articles of association, can include and refer to the pursuit of social goals, frame directors' duties and liabilities (although this is often already codified in the relevant company law legislation), clarify which matters the board views as material to the corporation and allow the board to pursue long-term strategies. ${ }^{120}$ This is already in line with corporate governance codes in some jurisdictions, ${ }^{121}$ as well as with rules and recommendations (in hard law and soft law) concerning non-financial reporting (NFR). ${ }^{122}$

\footnotetext{
116 See, e.g., the British Academy Project on the 'Future of the Corporation' (led by Colin Mayer) at https://www.thebritishacademy.ac.uk/documents/223/future-of-the-corporation-principles-purposefulbusiness-executive-summary.pdf (accessed 15 May 2021). The research suggests a need to develop a new framework for the corporation around a new definition of corporate purpose. This is their definition: 'Profitably solving the problems of people and planet, and not profiting from creating problems for people and planet'. They produced a set of new principles of purposeful business, focused on: law, regulation, ownership, governance, measurement, performance, finance and investment. Their framework for twenty-first century business is based on corporate purposes; commitments to trustworthiness; and ethical corporate cultures.

117 Hart and Zingales (2017), p 24.

118 See in this regard the Roundtable discussion 'Corporate Governance for a Changing World' (2016), p 23, https://papers.ssrn.com/sol3/papers.cfm?abstract_id=2805497 (accessed 15 May 2021). Purpose can be embedded in the governance structure through governance documents and share structure. A potential change to the 'objects clause' of the company could be linked to shareholder voting, i.e., a majority can agree to a change reflecting a broader purpose (see p 24, n 87): 'In UK Company Law, s31(1) CA 2006 allows companies to have an objects clause. Making the purpose explicit in an objects clause has the effect that directors are then under a duty to comply - and the objects clause can be entrenched s22(1) CA 2006 so as to create a hurdle for future changes.'

119 See here also the reform proposals of the SMART project, proposing that '[b]usiness must shift to sustainable business models and be encouraged to innovate sustainably. To achieve this, the purpose of business needs to be redefined towards sustainability, to protect the decision-makers in business against the pressure to maximise financial returns.' See generally Sjåfjell et al. (2020).

120 Roundtable discussion 'Corporate Governance for a Changing World' (n 118 above), p 24.

121 See, for example, the Netherlands and South Africa in this regard (n 118 above); Principle A on board leadership and company purpose in the 2018 UK Corporate Governance Code (2018 UKCGC) where reference is made to 'wider society'; and the blog post by Martin Lipton et al., https://corpgov.law. harvard.edu/2019/10/28/the-new-paradigm/ (accessed 15 May 2021), drawing attention to the alignment of the 2018 UKCGC and 2020 Stewardship Code with the World Economic Forum's 'The New Paradigm: A Roadmap for an Implicit Corporate Governance Partnership Between Corporations and Investors to Achieve Sustainable Long-Term Investment and Growth'.

122 See further Sect. 4.5 below. We see the use of purpose provisions in this context as an 'add-on' to our proposed model. Purpose provisions, in the UK for example, can be broadly drafted to state that directors should act in a sustainable manner. This approach would be aligned with s172 CA 2006 but require more than mere subjective consideration of stakeholder issues.
} 
Another example of a voluntary (or soft law) mechanism is provided by the new Provision 5 in the UKCGC on workforce engagement mechanisms. It takes the stakeholder agenda a step forward by requiring listed companies to adopt one of three options (i.e., a designated non-executive director ('NED'), a formal employee advisory council, or a director from the workforce) for workforce engagement. Unlike much of the history of the Code, in which the soft law provisions of the Code have generally run ahead of hard law, there is a clear link between the workforce engagement provision and the stakeholder focus on NFR, which has been implemented in hard law. We view this development as a key stage in the evolution of the UKCGC in terms of integrating stakeholder interests into board decision-making. ${ }^{123}$

\subsection{Implementation}

Implementation of our proposed entity model would have multiple effects. We address here the key impacts that we envisage for the scope of ESG investing, the portfolio effects for asset managers, the 'real-world' impact of ESG investing, and the role of 'stewardship'.

The entity model of ESG would broaden the scope of ESG as in principle all companies and all types of external finance would be covered. And while it is likely that, in line with the NFRD, only larger companies would initially be covered, the scope of regulation could be extended over time. ${ }^{124}$ In contrast, the legislative framework in the EU has to date been narrower in scope as it follows the financial model of ESG by focusing on various forms of asset management. ${ }^{125}$ While this approach is in principle open-ended and limited only by the type of assets held by

\footnotetext{
123 At a high level, the key statutory provision providing for integration of stakeholder interests (s172 CA 2006) is focused on outcome: it specifies that the board should consider the relevant stakeholder interests but provides no process for engagement with stakeholders or integration of their interests. The move to Provision 5 indicates a move towards some verification on what is required under s172 (i.e., the consideration of stakeholder interests), thus making provision for a more explicit process for the integration of a (limited set) of stakeholder interests. The shift towards specifying process also represents a move away from the reliance on disclosure as the primary regulatory technique that has been evident in the development of stakeholder interests through non-financial reporting. See further ChalaczkiewiczLadna et al. (2021).

124 The proposed UK model of TCFD-based climate-related disclosure provides a model that is more extensive in scope than that of the EU, albeit limited to the 'E' of ESG, see further https://www.gov.uk/ government/publications/uk-joint-regulator-and-government-tcfd-taskforce-interim-report-and-roadmap (accessed 15 May 2021). The EU Regulations referenced in $n 125$ below generally fall outside the 'onshoring' mechanism applicable to EU legislation taking effect before the end of the Brexit transitional period (under section 3 of the European Union (Withdrawal) Act 2018).

125 See the EU Disclosure Regulation (Regulation 2019/2088 on sustainability-related disclosures in the financial services sector [2019] OJ L317/1) and the EU Taxonomy Regulation (Regulation 2020/852 on the establishment of a framework to facilitate sustainable investment, and amending Regulation (EU) 2019/2088, [2020] OJ L198/13). A key pair of definitions for both Regulations is 'financial market participant' and 'financial product': working in tandem, they drive the disclosure obligations in the 2019 Regulation and the scope of the taxonomy provisions in the 2020 Regulation. See for 'financial market participant' Article 2(1) of the Disclosure Regulation and for 'financial product' Article 2(12) of that Regulation. The two definitions are functionally aligned so as to capture the products offered by the relevant participants.
} 
the relevant market participants, there are some key financial products that are likely to be either omitted or under-represented. The most obvious and substantial omission is bank loans, which represent a substantial element of EU and UK corporate funding, especially in the case of SMEs. ${ }^{126}$ Private equity and hedge fund managers are included as forms of 'alternative investment managers', but that still leaves a substantial gap in the coverage of unlisted companies, especially those that are either family or closely held businesses. ${ }^{127}$

The impact of our proposed entity model can be considered from two perspectives: the impact on a portfolio with some form of ESG strategy; and the impact on the 'real-world' effects of ESG investing. While ESG strategies may mitigate portfolio risk, ${ }^{128}$ they may not represent a viable long-term solution in the case of universal investors (such as pension funds). Those investors cannot diversify away from systemic risks such as climate change, inequality and pandemics, and can only mitigate whole-system threats by effecting change in the real economy. ${ }^{129}$ Moreover, the focus on portfolio risk/return in the financial model means that there is at best only an indirect focus on the 'real-world' effects (impact) of ESG investing. Thus, it has been found that holding green assets is not a sufficient strategy for generating green outcomes. Taking the perspective of ESG as a 'green' transmission mechanism operating across different asset classes, higher impact is observed in fixed income and private equity, less so in listed equity, despite the latter attracting most attention in the ESG-focused literature. ${ }^{130}$ That outcome may be linked to the propensity of

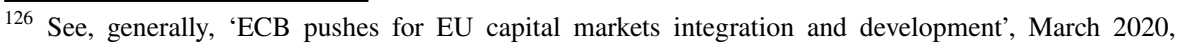
https://www.ecb.europa.eu/press/pr/date/2020/html/ecb.pr200303 5eaf4c119d.en.html (accessed 15 May 2021), showing the continued dominance of non-marketable financial instruments in the mix of corporate finance for EU companies, especially in the case of non-financial companies. We note the alignment with the Collective Commitment to Climate Action (CCCA) sponsored by the UNEP FI on the part of some global banks, but it represents less than $10 \%$ of global banking assets. See https://www.unepfi. org/banking/bankingprinciples/collective-commitment/ (accessed 15 May 2021). Moreover, since much of corporate lending is a on a 'general corporate purposes' basis, linkage of bank assets with real-world ESG effects is inherently problematic.

${ }^{127}$ Even among listed companies, there appears to be a bias in favour of larger capitalisation companies among ESG rating agencies: see Boffo and Patalano (2020).

${ }^{128}$ Boffo and Patalano (2020), p 10: 'The analysis also found that asset concentration associated with tilting portfolios toward high scoring ESG issuers can, depending on the conditions, affect volatility, riskadjusted returns and drawdown risk. Various combinations of constructed portfolios based on tilts that provide greater exposure to higher-scoring issuers often performed at or below traditional indices for periods of time. The results are consistent with portfolio theory in that, greater concentration of exposures in a given portfolio can increase volatility, all else equal. On the contrary, the analysis of maximum drawdown risk showed that ESG portfolios have a lower drawdown risk when compared to non-ESG portfolios.'

${ }^{129}$ See Quigley (2020), p 2: 'A positive investment approach, then, eschews stock-picking in the public markets in favour of a focus on primary market asset allocation-flows of new capital to the companies they own-and forceful stewardship within the secondary market. In essence, (S)RI and ESG aim to protect individual portfolios from systemic risks; universal owners aim to mitigate systemic risks in the real world, which has the effect of internalising externalities and protecting the long-term health of the system as a whole.'

${ }^{130}$ See Harnett et al. (2020), see n 47 above.
} 
different asset classes to finance new as opposed to established activities, with listed equity balanced more towards the old.

Compared with ESG techniques focused on the supply of capital (such as the financial model) the integration of ESG into board decision-making would in principle increase the monitoring and intervention role of investors ('stewardship'). This would be the natural consequence of freeing the supply of capital from ESG conditionality (i.e., moving ESG decision-making to the board), with the result that investor influence would in principle have to be channelled through stewardship. Thus, collaboration would be likely to increase, as would collective action by passive and long-term investors to focus on systemic risks (such as climate change). In overall terms, these changes would re-focus ESG on corporate governance at the entity and operational level, a process which has to date been subordinated to the focus on the role of the capital market in the financial model. ${ }^{131}$ Importantly, however, the relative power of stewardship as a driver for corporate decision-making would decline if stakeholders were empowered in the manner we envisage.

\subsection{Metrics}

As already indicated, there is no distinct set of metrics associated with CSR. Most of the metrics are framed in terms of ESG and are aimed at investors. The integration of ESG is often undertaken by reference to ESG ratings from agencies but the consistency and reliability of such ratings is a matter of widespread concern. ${ }^{132} \mathrm{We}$ do however see a role for metrics in the context of CSR and our entity model of ESG. In particular, the initiative of the World Economic Forum on stakeholder capitalism metrics could provide a standardised set of criteria that map onto our entity model. ${ }^{133}$ Although there have been a variety of different initiatives on ESG reporting in recent years, it is notable that Deloitte, EY, KPMG and PwC have collaborated with the Forum in identifying

a set of universal, material ESG metrics and recommended disclosures that could be reflected in the mainstream annual reports of companies on a consistent basis across industry sectors and countries. ${ }^{134}$

\footnotetext{
${ }^{131}$ But see the (forthcoming) ICGN 2020 CG Principles for a rare example of reference to ESG in the context of CG Principles to be applied by operating companies. UKCG 2018 refers to sustainability but not ESG.

${ }^{132}$ See, e.g., Boffo and Patalano (2020), p 10: '[...] ESG ratings can vary greatly from one ESG provider to another. The different methodologies used to translate raw data into a more sophisticated rating suffer some level of criticism because of the wide variance in the results. This implies that if investors are using and relying on different service providers, the score inputs that shape securities selection and weighting could be driven by choice of rating provider.'

${ }^{133}$ In 2020 the WEF white paper, https://www.weforum.org/reports/measuring-stakeholder-capitalismtowards-common-metrics-and-consistent-reporting-of-sustainable-value-creation (accessed 15 May 2021), set out 21 core metrics and 34 expanded metrics, covering environmental, social and governance (ESG) issues ranging from emissions to social factors such as pay and gender ratios and governance targets. See also Barby et al. (2021).

${ }^{134}$ The WEF framework is the preferred model of the influential Institute and Faculty of Actuaries (IFoA). See IFoA 'The best ESG reporting framework for your business', https://www.rio.ai/hubfs/ESG\%
} 
Such metrics would also support the entity model by providing a clearer framework for directors' decision-making as well as the due diligence standard, discussed above.

\subsection{Reporting}

At the global level, the focus on sustainability led to the development of 'double materiality' as a concept that captured both financial materiality and the company's own social and environmental impacts. ${ }^{135}$ In principle that approach is neutral, as between the financial and entity models, ${ }^{136}$ but its development in the EU, as the global leader on ESG, demonstrates a clear bias towards the financial model. The financial model of ESG investing prioritises disclosure as the key mechanism for driving the transition to a sustainable economy, based on the premise that the supply of capital would be the principal driver.

Taking the EU regulatory model as an example, this approach led to the development of two forms of disclosure: 'reporting', such as financial or non-financial reporting to shareholders and stakeholders; and transaction or product-related disclosure in the context of financial markets. ${ }^{137}$ The earlier approach of the EU, in the form of the NFR Directive, ${ }^{138}$ was closer in its design to our proposed entity model in that it focused on the first form of reporting and implicitly recognised the role of stakeholders in driving corporate decision-making towards a sustainable model. Later developments in the EU framework reflect concern that

non-financial reporting requirements have proven insufficient to overcome pressures to focus on short-term financial performance and to influence companies and their investors to prioritise sustainability'. ${ }^{139}$

That led to some adjustments to NFR introduced by the Taxonomy Regulation so as to align it more closely with the more systematic and rigorous approach to

\footnotetext{
Footnote 134 (continued)

20Reporting\%20Frameworks\%20Guide.pdf (accessed 15 May 2021), p 28: '[...] we like the WEF framework because it incorporates the most important aspects of a number of other frameworks (CDP, CDSB, GRI, IIRC and SASB) and ties in closely with the SDGs.'

135 See https://29kjwb3armds2g3gi4lq2sx1-wpengine.netdna-ssl.com/wp-content/uploads/Statement-ofIntent-to-Work-Together-Towards-Comprehensive-Corporate-Reporting.pdf (accessed 15 May 2021) (see Fig. 1, p 5, Dynamic materiality).

136 See, e.g., ICGN 2020 CG Principles (forthcoming), referencing 'double materiality' as an element of ESG reporting, encompassing the company's own social and environmental impacts as well as how ESG factors may impact the company's own financial performance. This is focused on corporate reporting (entity model).

137 These two forms of disclosure are embedded in the EU Disclosure and Taxonomy Regulations respectively, see $\mathrm{n} 125$ above.

138 See $n 41$ above.

139 See the EY Study for the European Commission (n 104 above), p 39. See also Hess (2018), p 10: '[...] to the extent that policy makers rely on general transparency initiatives to improve companies' human rights performance and exclude consideration of alternative policy interventions (including other transparency-based regulatory options), they are creating a "transparency trap" that does not further their stated goals.'
} 
sustainability in the latter. ${ }^{140}$ But it remains the case that NFR and the later taxonomy/disclosure regimes are not aligned ${ }^{141}$ and differ in their respective focus on the entity and financial channels as transmission mechanisms for ESG. ${ }^{142}$

Less reliance on disclosure, and with a procedural version of a duty of due diligence as outlined at 4.2 above, would be an important element in moving from a financial to an entity model of ESG. ${ }^{143}$ As a regulatory technique, disclosure has many attractions but also some shortcomings. For example, it is often difficult to report on performance outcomes and easier to rather report on policies and procedures. A company can report on what policies they have in place, but they cannot accurately report on the effectiveness of such policies. Thus, we found in earlier research that the main reason for disclosing non-financial information is purely compliance, while genuine interest in ESG matters is at the bottom of the list. ${ }^{144}$ Companies often use the reports as a tool to manage the public's impression of the company (so-called 'greenwashing') rather than to make meaningful changes to respect human rights, for example. ${ }^{145}$ Our proposal to expand s172 reporting to include the operation of a stakeholder board committee would not of itself overcome those shortcomings but it would at least facilitate more effective stakeholder integration into board decision-making.

\section{Conclusions}

As outlined in Sect. 2, we observe that the evolution of ESG over time reveals fundamental differences between CSR, sustainability and ESG. The early development of CSR was marked by a focus on ethics and accountability, sustainability then focused on externalities and stakeholders, while the advent of ESG focused attention on adjusting the supply of capital to reflect risks to portfolio returns. The three strands overlapped to

\footnotetext{
140 Note in this regard the linkage between the NFR Directive (2014/95) and the Taxonomy Regulation (2020/852). The latter (Article 8) extends NFR disclosure to include the proportions of turnover and capital expenditure linked to activities classified as environmentally sustainable under Articles 3 and 9 of the Taxonomy Regulation.

141 See recital 25 of the EU Disclosure Regulation, n 125 above.

142 But the more recent focus on developing an EU sustainability reporting standard to be implemented in tandem with the revised version of the NFR Directive signals the potential for clearer alignmentsee EFRAG proposals for a relevant and dynamic EU sustainability reporting standard-setting (February 2021), https://ec.europa.eu/info/files/210305-report-efrag-sustainability-reporting-standard-setting_en (accessed 15 May 2021).

143 This does not imply that transaction or product-related disclosure of ESG information in the investment chain has no value. It does, but its role should be focused on principal-agent issues in that context (as per Stewardship Codes) and not, more ambitiously, on changing corporate governance to resolve sustainability issues.

144 These conclusions are based on interviews where qualitative information was gathered from stakeholders on how they perceive and use the strategic report. The interviews concerned two research questions. First, whether compliance with the statutory strategic report requirements provides stakeholders with adequate information to facilitate understanding of how companies integrate ESG issues into decision-making; and second, whether strategic reporting forms a basis for stakeholder engagement. See Esser et al. (2020).

145 Hess (2018).
} 
a considerable extent in form and function but there remained underlying tensions that made them difficult to reconcile. We argue that sustainability (as the overarching concept) could not easily be combined with both CSR and ESG as techniques for implementation. That led to a struggle for supremacy in which ESG emerged as the clear winner.

We link that outcome to the instrumental role of fiduciary duty in setting the legal framework underpinning CSR and ESG respectively. We highlight first the role of asymmetry in the two forms of fiduciary duty: corporate fiduciary duty in the case of CSR and 'intermediary fiduciary duty' in the case of ESG. The presence of asymmetry necessitated a choice between two different approaches. We argue that greater legal uncertainty in the case of corporate fiduciary duty was a key factor that limited the potential for development of CSR by comparison with ESG. In that sense, CSR posed greater legal risk for directors than ESG did for fiduciary investment managers.

We conclude by sketching the contours of an entity model of ESG investing, which is inspired by the earlier CSR tradition. It includes some key legal reforms, in particular a duty of due diligence, which has already been implemented in some countries, with the EU likely to follow soon. The model includes a role for soft law and voluntary action in recognition of the important steps that have already been taken in that direction by investors. But ultimately, we believe that more meaningful and enduring action requires hard law intervention in connection with a duty of due diligence. Our proposal, framed in the context of the UK system, would avoid the changes to directors' duties and enforcement implicit in the proposed EU model, but could nevertheless drive significant change through more effective integration of stakeholders in corporate decision-making.

Acknowledgements This article is based on our understanding of law and regulation as of 15 May 2021. We are grateful for comments from participants at the National University of Singapore conference 'Sustainable Finance and Capital Markets' on 16 April 2021 and the LSE-UCL Law and Finance Seminar Series webinar on 4 May 2021.

Open Access This article is licensed under a Creative Commons Attribution 4.0 International License, which permits use, sharing, adaptation, distribution and reproduction in any medium or format, as long as you give appropriate credit to the original author(s) and the source, provide a link to the Creative Commons licence, and indicate if changes were made. The images or other third party material in this article are included in the article's Creative Commons licence, unless indicated otherwise in a credit line to the material. If material is not included in the article's Creative Commons licence and your intended use is not permitted by statutory regulation or exceeds the permitted use, you will need to obtain permission directly from the copyright holder. To view a copy of this licence, visit http://creativecommons.org/licen ses/by/4.0/.

\section{References}

Agudelo MAL, Jóhannsdóttir L, Davídsdóttir B (2019) A literature review of the history and evolution of corporate social responsibility. Int J Corp Soc Responsib. https://doi.org/10.1186/ s40991-018-0039-y

Amel-Zadeh A, Serafeim G (2017) Why and how investors use ESG information: evidence from a global survey. https://hbswk.hbs.edu/item/why-and-how-investors-use-esg-information-evidence-from-aglobal-survey. Accessed 15 May 2021 
Antoncic M, Bekaert G, Rothenberg R, Noguer M (2020) Sustainable investment-exploring the linkage between alpha, ESG, and SDG's. https://papers.ssrn.com/sol3/papers.cfm?abstract_id=36234 59. Accessed 15 May 2021

Barby C et al. (2021) Measuring purpose: an integrated framework. https://ssrn.com/abstract=3771892. Accessed 15 May 2021

Bebchuk LA, Tallarita R (2020) The illusory promise of stakeholder governance. Cornell Law Review 106:91-178. Harvard Law School John M. Olin Center Discussion Paper No. 1052. Harvard Law School Program on Corporate Governance Working Paper 2020-1. https://ssrn.com/abstract=35449 78. Accessed 15 May 2021

Boffo R, Patalano R (2020) ESG investing: practices, progress and challenges. OECD, Paris. https:// www.oecd.org/finance/ESG-Investing-Practices-Progress-and-Challenges.pdf. Accessed 15 May 2021

Bonnitcha J, McCorquodale R (2017) The concept of 'due diligence' in the UN Guiding Principles on Business and Human Rights. Eur J Int Law 28(3):899-919

Bowen HR (1953) Social responsibilities of the businessman. Harper, New York

Brakman Reiser D (2012-2013) Theorising forms for social enterprise. Emory L J 62:681

British Academy (2019) The future of the corporation: principles for purposeful business. https://www. thebritishacademy.ac.uk/publications/future-of-the-corporation-principles-for-purposeful-business. Accessed 15 May 2021

Cabrelli D, Esser I-M (2018) A rule-based comparison and analysis of the case studies. In: Siems M, Cabrelli D (eds) Comparative company law: a case-based approach (2nd edn). Hart Publishing, Oxford

Carroll AB (1979) A three-dimensional conceptual model of corporate performance. Acad Manag Rev 4(4):497-505

Carroll AB (2008) A history of corporate social responsibility: concepts and practices. In: Crane A, McWilliams A, Matten D, Moon J, Siegel D (eds) The Oxford handbook of corporate social responsibility. Oxford University Press

Chalaczkiewicz-Ladna K, Esser I, MacNeil I (2021) Workforce engagement and the UK Corporate Governance Code. https://papers.ssrn.com/sol3/papers.cfm?abstract_id=3834387. Accessed 15 May 2021

Chiu IHY, Katelouzou D (2018) Making a case for regulating institutional shareholders' corporate governance roles. J Bus Law 1:67-99

Deutsche Bank Group (2012) Sustainable investing establishing long-term value and performance, https://www.researchgate.net/publication/256048484_Sustainable_Investing_Establishing_LongTerm_Value_and_Performance. Accessed 15 May 2021

Elkington J (1994) Towards the sustainable corporation: win-win-win business strategies for sustainable development. Calif Manag Rev 36(2):90-100

Elkington J (1999) Cannibals with forks: triple bottom line of 21st century business. Capstone Publishing, Oxford

Epstein EM (1987) The corporate social policy process: beyond business ethics, corporate social responsibility, and corporate social responsiveness. Calif Manag Rev 29:99-114. https://doi.org/10.2307/ 41165254. Accessed 15 May 2021

Esser I-M (2019) Regulating ESG issues: a comparison of South Africa and the United Kingdom. In: Coetzee H, Fritz C (eds) De serie legenda: developments in commercial law: entrepreneurial law, vol III. LexisNexis South Africa, Durban

Esser I-M, Delport PA (2017a) The protection of stakeholders: the South African social and ethics committee and the United Kingdom's enlightened shareholder value approach: part 1. De Jure 50(1):97-110

Esser I-M, Delport PA (2017b) The protection of stakeholders: the South African social and ethics committee and the United Kingdom's enlightened shareholder value approach: part 2. De Jure 50(2):221-240

Esser I-M, MacNeil I (2019) Disclosure and engagement: stakeholder participation mechanisms. Eur Bus Law Rev 30(2):201-222

Esser I-M, MacNeil I, Chalaczkiewicz-Ladna K (2018) Engaging stakeholders in corporate decisionmaking through strategic reporting: an empirical study of FTSE 100 companies. Eur Bus Law Rev 29(5):729-772 
Esser I-M, MacNeil I, Chalaczkiewicz-Ladna K (2020) Engaging stakeholders in corporate decisionmaking through strategic reporting: an empirical study of FTSE 100 companies (part 2). Eur Bus Law Rev 31(2):209-242

Ferrarini G (2020) Corporate purpose and sustainability. European Corporate Governance Institute Law Working Paper \#559/2020. https://ssrn.com/abstract=3753594. Accessed 15 May 2021

Fisch JE, Davidoff Solomon S (2021) Should corporations have a purpose? Texas Law Review, forthcoming. U of Penn, Inst for Law \& Econ Research Paper No. 20-22. European Corporate Governance Institute—Law Working Paper No. 510/2020. https://ssrn.com/abstract=3561164. Accessed 15 May 2021

Freeman RE (1984) Strategic management: a stakeholder approach. Pitman

Harnett E, Caldecott B, Clark A, Koskelo K (2020) Sustainable finance and transmission mechanisms to the real economy. http://ccsi.columbia.edu/2020/09/09/grasfi2020/. Accessed 15 May 2021

Harper Ho VE, Park S (2020) ESG disclosure in comparative perspective: optimizing private ordering in public reporting. Univ Pa J Int Law 41(2), 2019. https://ssrn.com/abstract=3470991. Accessed 15 May 2021

Hart O, Zingales L (2017) Companies should maximize shareholder welfare not market value. J Law Finance Account 2:247-274

Hazen TL (2020) Social issues in the spotlight: the increasing need to improve publicly held companies' CSR and ESG disclosures. U Pa J Bus L 23:740-796. https://ssrn.com/abstract=36153 27 or https://doi.org/10.2139/ssrn.3615327. Accessed 15 May 2021

Heald M (1970) The social responsibilities of business: company and community 1900-1960. Press of Case Western Reserve University

Hess D (2018) The transparency trap: non-financial disclosure and the responsibility of business to respect human rights. Am Bus Law J 56(1):5-53. https://doi.org/10.13140/RG.2.2.10315.85283. Accessed 15 May 2021

Impact Investing Institute (2020) Impact investing by pension funds, fiduciary duty-the legal context. https://www.impactinvest.org.uk/wp-content/uploads/2020/11/Impact-investing-by-pensionfunds-Fiduciary-duty-\%E2\%80\%93-the-legal-context.pdf. Accessed 15 May 2021

Johnson LPQ, Millon DK (2015) Corporate law after Hobby Lobby. Bus Law 70(1), 2015

Johnston A (2017) The shrinking scope of CSR in UK corporate law. Wash. \& Lee L. Rev. 741001 (2017). https://scholarlycommons.law.wlu.edu/wlulr/vol74/iss2/16. Accessed 15 May 2021

Johnston A et al. (2019) Corporate governance for sustainability. https://ssrn.com/abstract=3502101. Accessed 15 May 2021

Jones TM (1980) Corporate social responsibility revisited, redefined. Calif Manag Rev 22(3):59-67. https://doi.org/10.2307/41164877. Accessed 15 May 2021

Katelouzou D, Klettner A (2020) Sustainable finance and stewardship: unlocking stewardship's sustainability potential. (An edited version of the paper will be published as a chapter in Katelouzou D, Puchniak DW (eds) Global shareholder stewardship: complexities, challenges and possibilities. Cambridge University Press (forthcoming)). European Corporate Governance InstituteLaw Working Paper No. 521/2020. https://ssrn.com/abstract=3578447. Accessed 15 May 2021

Katelouzou D, Siems M (2020) The global diffusion of stewardship codes. (An edited version of the paper will be published as a chapter in Katelouzou D, Puchniak DW (eds) Global shareholder stewardship: complexities, challenges and possibilities. Cambridge University Press (forthcoming)). European Corporate Governance Institute-Law Working Paper No. 526/2020. King's College London Dickson Poon School of Law Legal Studies Research Paper Series: Paper No. 2020-41. LawFin Working Paper No. 10. https://ssrn.com/abstract=3616798. Accessed 15 May 2021

Keay A (2010) The duty to promote the success of the company: is it fit for purpose? Univ. of Leeds Sch. of Law, Ctr. for Bus. Law \& Practice Working Paper. https://papers.ssrn.com/sol3/papers. cfm?abstractid $=1662411$. Accessed 15 May 2021

Leicester A (2013) Environmental taxes; economic principles and the UK experience. https://www. ifs.org.uk/docs/chapter_leicester_uk2.pdf. Accessed 15 May 2021

MacNeil I (2009) Uncertainty in commercial law. Edinb Law Rev 13(1):68-99

MacNeil I (2010a) Activism and collaboration among shareholders in UK listed companies. Cap Mark Law J 5(4):419-438

MacNeil I (2010b) The trajectory of regulatory reform in the UK in the wake of the financial crisis. Eur Bus Org Law Rev 11(4):483-526 
MacNeil I (2012) An introduction to the law on financial investment, 2nd edn. Hart Publishing, Oxford

MacNeil I, Esser I-M (2020) The pandemic response in the UK in the context of corporate and financial law-within and without law. https://ssrn.com/abstract=3636292. Accessed 15 May 2021

MacNeil I, Esser I-M (2021) The emergence of 'comply or explain' as a global model for corporate governance codes. European Business Law Review (forthcoming, 2022). https://ssrn.com/abstract= 3775736. Accessed 15 May 2021

Martin-Ortega O (2013) Human rights due diligence for corporations: from voluntary standards to hard law at last? Neth Q Hum Rights 32(1):44-74

Moncrieff L (2015) Karl Polanyi and the problem of corporate social responsibility. J Law Soc 42(3):434-459

Palley TI (2007) Financialization, what it is and why it matters. Working Paper No 525, The Levy Economics Institute and Economics for Democratic and Open Societies Washington, D.C. http://www. levyinstitute.org/pubs/wp_525.pdf. Accessed 15 May 2021

Pollman E (2019) Corporate social responsibility, ESG and compliance. In: Sokol DD, van Rooij B (eds) Cambridge handbook of compliance. Cambridge University Press

Quigley E (2020) Universal ownership in practice: a practical positive investment framework for asset owners. https://papers.ssrn.com/sol3/papers.cfm?abstract_id=3638217. Accessed 15 May 2021

Rock EB (2020) For whom is the corporation managed in 2020?: the debate over corporate purpose. European Corporate Governance Institute-Law Working Paper No. 515/2020. NYU School of Law, Public Law Research Paper No. 20-16. NYU Law and Economics Research Paper. https://ssrn. com/abstract $=3589951$. Accessed 15 May 2021

Rühmkorf A (2015) Corporate social responsibility, private law and global supply chains. Edward Elgar Publishing

Schanzenbach MM, Sitkoff RH (2020) Reconciling fiduciary duty and social conscience: the law and economics of ESG investing by a trustee. Stanf Law Rev 74:381-454

Sjåfjell B, Taylor MB (2015) Planetary boundaries and company law: towards a regulatory ecology of corporate sustainability. University of Oslo Faculty of Law Research Paper No. 2015-11. https:// ssrn.com/abstract=2610583. Accessed 15 May 2021

Sjåfjell B, Taylor MB (2019) Clash of norms: shareholder primacy vs. sustainable corporate purpose. Int Comp Corp Law J 13(3):40-66

Sjåfjell B, Mähönen JT, Novitz TA, Gammage C, Ahlström H (2020) Securing the future of European business: SMART reform proposals. University of Oslo Faculty of Law Research Paper No. 202011. Nordic \& European Company Law Working Paper No. 20-08. https://ssrn.com/abstract=35950 48. Accessed 15 May 2021

Stout L (2002) Bad and not-so-bad arguments for shareholder primacy. South Calif Law Rev 75(5):1189-1210

Stout L (2012) The shareholder value myth. Berrett-Koehler Publishers Inc, San Francisco

Publisher's Note Springer Nature remains neutral with regard to jurisdictional claims in published maps and institutional affiliations. 